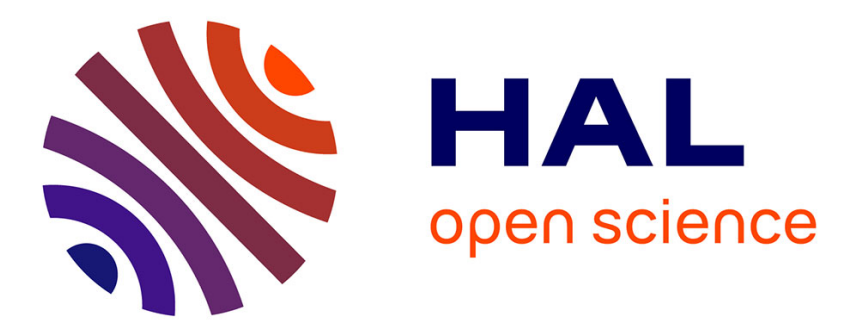

\title{
UNBS1450; a steroid cardiac glycoside inducing apoptotic cell death in human leukemia cells
}

Tom Juncker, Claudia Cerella, Marie-Hélène Teiten, Franck Morceau, Marc

Schumacher, Jenny Ghelfi, Michael Schnekenburger, Estelle Henry, Mario

Dicato, Marc Diederich

\section{To cite this version:}

Tom Juncker, Claudia Cerella, Marie-Hélène Teiten, Franck Morceau, Marc Schumacher, et al.. UNBS1450; a steroid cardiac glycoside inducing apoptotic cell death in human leukemia cells. Biochemical Pharmacology, 2010, 81 (1), pp.13. 10.1016/j.bcp.2010.08.025 . hal-00642425

\section{HAL Id: hal-00642425 \\ https://hal.science/hal-00642425}

Submitted on 18 Nov 2011

HAL is a multi-disciplinary open access archive for the deposit and dissemination of scientific research documents, whether they are published or not. The documents may come from teaching and research institutions in France or abroad, or from public or private research centers.
L'archive ouverte pluridisciplinaire HAL, est destinée au dépôt et à la diffusion de documents scientifiques de niveau recherche, publiés ou non, émanant des établissements d'enseignement et de recherche français ou étrangers, des laboratoires publics ou privés. 


\section{Accepted Manuscript}

Title: UNBS1450; a steroid cardiac glycoside inducing apoptotic cell death in human leukemia cells

Authors: Tom Juncker, Claudia Cerella, Marie-Hélène Teiten, Franck Morceau, Marc Schumacher, Jenny Ghelfi, Michael Schnekenburger, Estelle Henry, Mario Dicato, Marc Diederich

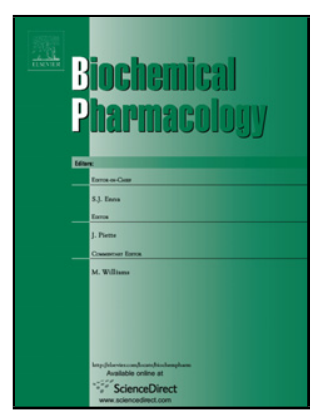

PII: S0006-2952(10)00656-8

DOI: doi:10.1016/j.bcp.2010.08.025

Reference: BCP 10705

To appear in: $\quad B C P$

Received date: $\quad 14-6-2010$

Revised date: $\quad 26-8-2010$

Accepted date: $\quad 27-8-2010$

Please cite this article as: Juncker T, Cerella C, Teiten M-H, Morceau F, Schumacher M, Ghelfi J, Schnekenburger M, Henry E, Dicato M, Diederich M, UNBS1450; a steroid cardiac glycoside inducing apoptotic cell death in human leukemia cells, Biochemical Pharmacology (2010), doi:10.1016/j.bcp.2010.08.025

This is a PDF file of an unedited manuscript that has been accepted for publication. As a service to our customers we are providing this early version of the manuscript. The manuscript will undergo copyediting, typesetting, and review of the resulting proof before it is published in its final form. Please note that during the production process errors may be discovered which could affect the content, and all legal disclaimers that apply to the journal pertain. 
UNBS1450, a steroid cardiac glycoside inducing apoptotic cell death in human leukemia cells

Tom Juncker ${ }^{*}$, Claudia Cerella*, Marie-Hélène Teiten ${ }^{*}$, Franck Morceau, Marc Schumacher, Jenny Ghelfi, Michael Schnekenburger, Estelle Henry, Mario Dicato and Marc Diederich

Laboratoire de Biologie Moléculaire et Cellulaire du Cancer, Fondation de Recherche Cancer et Sang, Hôpital Kirchberg, 9 Rue Edward Steichen, 2540 Luxembourg, Luxembourg

*Equal contribution

Address correspondence to: Marc Diederich, Laboratoire de Biologie Moléculaire et Cellulaire du Cancer, Hôpital Kirchberg, 9 rue Edward Steichen, L-2540 Luxembourg, Luxembourg. Tel : +352-2468-4040 ; Fax : +352-2468-4060 ; E-mail address:

marc.diederich@1bmcc.lu 


\begin{abstract}
Cardiac steroids are used to treat various diseases including congestive heart failure and cancer. The aim of this study was to investigate the anti-leukemic activity of UNBS1450, a semi-synthetic cardenolide belonging to the cardiac steroid glycoside family. Here, we report that, at low nanomolar concentrations, UNBS1450 induces apoptotic cell death. Subsequently, we have investigated the molecular mechanisms leading to apoptosis activation. Our results show that UNBS1450 inhibits NF- $\mathrm{KB}$ transactivation and triggers apoptosis by cleavage of pro-caspases 8,9 and 3/7, by decreasing expression of anti-apoptotic Mcl-1 and by recruitment of pro-apoptotic Bak and Bax protein eventually resulting in cell death.
\end{abstract}

\title{
KEYWORDS
}

UNBS1450; NF-кB; apoptosis; cardenolide; cancer 


\section{Introduction}

Most anti-cancer drugs are isolated from natural sources or are at least bearing close structural relationships to natural compounds. Both, marine and terrestrial organisms are considered today as important sources for novel lead compounds.

Non-cardiotonic steroid glycosides obtained from the tropical plant Calotropis procera possess anti-cancer potential via binding to the $\alpha 3 \beta 1 \mathrm{Na}^{+} / \mathrm{K}^{+}$-ATPase isozymes. The cardenolide UNBS1450 (Figure 1A) has been analyzed in vitro as well as in vivo on non small cell lung cancer (NSCLC) and glioblastoma xenograft mice models [1, 2]. UNBS1450 is a chemically modified form of 2-oxovoruscharin, a derivative of voruscharin ; despite its already promising anti-cancer potential, the high toxicity of 2-oxovoruscharin required chemical modifications to improve tolerance in vivo [3]. The improved semi-synthetic compound UNBS1450 revealed itself to be significantly less toxic when compared to its mother compound and in the same time was proven to be even more potent in cancer therapy: with an average MTD of up to $120 \mathrm{mg} / \mathrm{kg}$, chronic administration increased mouse survival and reduced glioblastoma cell migration. Mijatovic et al. showed that UNBS1450-mediated antitumor activity is due to activation of non-apoptotic cell death mechanisms in $\mathrm{Na}^{+} / \mathrm{K}^{+}-$ ATPase $\alpha 1$ over-expressing glioma cells [4]. UNBS1450 has the capacity to disorganize nucleolar structure and functions via impairment of cyclin-dependent kinase and c-Myc expressions accompanied by disorganization of cancer cell-specific perinucleolar bodies. This non-apoptotic cancer cell death was a new cardenolide-induced mechanism of antitumor action [5] and this drug was described to be able to circumvent glioblastoma resistance to apoptosis [6].

Nuclear factor (NF)- $\mathrm{B}$ has been shown previously to be implicated in (1) cell death (apoptosis), (2) cell adhesion, (3) cell proliferation, (4) innate- and adaptive-immune response and (5) cancer development. This dimeric protein complex can both induce and repress gene expression, by binding to DNA sequences found in promoter and enhancer regions. NF- $\mathrm{KB}$ hetero- and homodimers can be constituted of five different family members: RelA (p65),

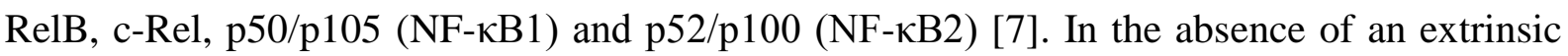

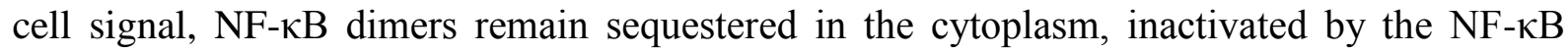
inhibitor IкB. Upon cell stimulation by cytokines, proliferating agents, carcinogens or

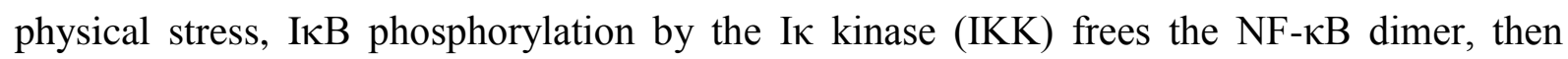
rapidly translocating into the nucleus and transactivating more than 550 genes. 
Deregulation of NF- $\mathrm{KB}$ leads to various pathologies including chronic inflammations and cancer [8]. NF- $\mathrm{kB}$ has become a major target in drug engineering. To date, a number of natural NF-kB inhibitors are being investigated, many of them being plant-derived isoprenoids and polyphenols.

As NF- $\mathrm{kB}$ is responsible for increased cell resistance towards possible cytocidal treatments currently applied in clinics, apoptosis induction through NF- $\kappa B$ inhibition and/or extrinsic and intrinsic pathway activation is considered as a main aim in cancer research. Apoptosis induction through NF- $\mathrm{kB}$ inhibition and subsequent extrinsic and intrinsic cell death pathway activation is considered a main target in cancer research. During apoptosis induction, many different activation cascades eventually lead to caspase- 3 or -7 cleavage and subsequent cell death [9].

In the absence of concluding investigations of anti-cancer effects of UNBS1450 in human leukemia cells, we hereby analyzed the effect of UNBS1450 on activation of cell death mechanisms and NF- $\mathrm{kB}$ pathway inhibition in human leukemia cells and demonstrate for the first time that nanomolar concentrations of UNBS1450 induce canonical apoptotic cell death mechanisms. 


\section{Material and Methods}

\subsection{Compounds and purification}

TNF $\alpha$ was purchased from Sigma-Aldrich (Bornem, Belgium) and dissolved to a concentration of $10 \mathrm{mg} / \mathrm{mL}$ in PBS $1 \mathrm{X}$ supplemented with $0,5 \%(\mathrm{w} / \mathrm{v}) \mathrm{BSA}$ according to the manufacturer's instructions.

UNBS1450 was a gift of Unibioscreen (Pr Robert Kiss, Brussels, Belgium): the compound, with a molecular weight of $605.8 \mathrm{~g}$ and received as dry powder, was solubilized in $52.95 \%$ DMSO (Sigma-Aldrich, Bornem, Belgium) and then further diluted to $5 \%$ DMSO/95 $\% \mathrm{H}_{2} 0$ to get working aliquots with a concentration of $5 \mathrm{mM}$. Both were frozen at $20{ }^{\circ} \mathrm{C}$. Control cells were treated with equivalent amounts of DMSO.

\subsection{Cell culture}

K562 (human chronic myelogenous leukemia), U937 (histiocytic lymphoma), Jurkat (T-cell leukemia), Raji (Burkitt's Lymphoma), Hel (erythroleukemia), Molt (human acute lymphoblastic leukemia), Meg01 (human megacaryoblastic cells), HL60 (human promyelocytic leukemia), TF1 (erythroleukemia) and KBM5 (chronic myelogenous leukemia) cells (DSMZ) were cultured in RPMI medium (Lonza, Verviers, Belgium) supplemented with $10 \%(\mathrm{v} / \mathrm{v})$ fetal calf serum (Lonza, Verviers, Belgium) and $1 \%(\mathrm{v} / \mathrm{v})$ antibiotic-antimycotic (BioWhittaker, Verviers, Belgium) at $37{ }^{\circ} \mathrm{C}$ and $5 \%$ of $\mathrm{CO}_{2}$. At $\mathrm{T}_{0}$ cells had been pre-treated with UNBS1450 at various concentrations. At $\mathrm{T}_{0}+2 \mathrm{~h}$ cells were activated by TNF $\alpha(20 \mathrm{ng} / \mathrm{mL})$.

Healthy blood samples were kindly donated as buffy coats by the Red Cross (Luxembourg, Luxembourg). By applying diluted (1/3) blood onto a Ficoll layer followed by centrifugation (400 g, 20 min), mononuclear cells were isolated and collected. The isolated peripheral blood mononuclear cells (PBMC) were kept in culture at $37{ }^{\circ} \mathrm{C}$ and $5 \% \mathrm{CO}_{2}$ for 24 $\mathrm{h}$ before they were subjected to treatments.

\subsection{Electrophoretic mobility shift assay (EMSA)}

Both, K562 and Jurkat cells, cultured in growth medium (RPMI, $10 \%$ FCS) at a concentration of $3 * 10^{5}$ cells/mL, were pre-treated or not for $2 \mathrm{~h}$ with UNBS1450 respectively at $40 \mathrm{nM}$ and $20 \mathrm{nM}$ before being activated by TNF $\alpha(20 \mathrm{ng} / \mathrm{mL})$ for $6 \mathrm{~h}$. Cells were then harvested and washed twice in PBS 1X; supernatants were discarded and cell pellets were stored overnight at $-80{ }^{\circ} \mathrm{C}$. Nuclear protein extractions were performed as described 
previously before being stored at $-80{ }^{\circ} \mathrm{C}[10]$. The oligonucleotide NF- $\kappa B c$ (consensus NFкB site) (Eurogentec, Liège, Belgium) (5'-AGTTGAGGGGACTTTCCCAGGC-3') and its complementary sequence were used as probe. After being hybridized, the probes were radiolabelled using $\left[\mathrm{g}-{ }^{32} \mathrm{P}\right] \mathrm{ATP}$ (MP Biomedicals, Illkirch, France) and the EMSA assay was realized according to conditions established before [10].

\subsection{Transient transfection and luciferase reporter gene assay}

K562 and Jurkat cells were transiently transfected as described previously [10]. For each electroporation we used $5 \mu \mathrm{g}$ of a luciferase reporter gene construct containing five repeats of a consensus NF-kB site (Stratagene, Genomics Agilent, Diegem, Belgium) and 5 $\mu \mathrm{g}$ of a Renilla luciferase plasmid (Promega, Leiden, Netherlands). Cells were resuspended in normal culture medium (RPMI, $10 \%$ FCS) after electroporation and cultured at $37^{\circ} \mathrm{C}$ and 5 $\% \mathrm{CO}_{2}$ for $24 \mathrm{~h}$. After the required incubation time, cells were harvested and resuspended in fresh growth medium (RPMI, $10 \%$ FCS) to a final concentration of $3 * 10^{5}$ cells $/ \mathrm{mL}$ and pretreated for $2 \mathrm{~h}$ with UNBS1450 $40 \mathrm{nM}$ for K562 and $20 \mathrm{nM}$ for Jurkat. Activation with 20 $\mathrm{ng} / \mathrm{mL}$ of TNF $\alpha$ for $6 \mathrm{~h}$ followed the pre-treatment. After the $8 \mathrm{~h}$ of total challenge, $75 \mu \mathrm{L}$ of Dual-Glo ${ }^{\mathrm{TM}}$ Luciferase Reagent (Promega, Leiden, Netherlands) were added to $75 \mu \mathrm{L}$ of the cellular suspension for a $10 \mathrm{~min}$ incubation at $22{ }^{\circ} \mathrm{C}$ before luciferase activity measurement. Further on, $75 \mu \mathrm{L}$ of Dual-Glo ${ }^{\mathrm{TM}}$ Stop\&Glo ${ }^{\circledR}$ Reagent (Promega, Leiden, Netherlands) were added for $10 \mathrm{~min}$ at $22{ }^{\circ} \mathrm{C}$ to the cell suspension to assay Renilla activity. An Orion microplate luminometer (Berthold) was used to measure luciferase and Renilla activity. The results are expressed as a ratio of arbitrary units of firefly luciferase activity normalized to Renilla luciferase activity.

\subsection{Cell viability assessment}

Percentages of cell survival were evaluated using Promega's CellTiter-Glo® Luminescent Cell Viability Assay (Promega, Leiden, Netherlands) kit, according to manufacturer's instructions. Alternatively, Trypan Blue staining was used to determine cell integrity. Data were normalized to the control and reported as percentage of viable cells.

\subsection{Analysis of apoptosis}

Analysis of nuclear fragmentation. Percentages of apoptotic cells, quantified as the fraction of apoptotic nuclei, were assessed by fluorescence microscopy (Leica-DM IRB 
microscope, Lecuit, Luxemburg) upon staining with the DNA-specific dye Hoechst 33342 (Sigma-Aldrich, Bornem, Belgium) as previously described [11]. The fraction of cells with nuclear apoptotic morphology was counted (at least 300 cells in at least three independent fields). The images were analyzed using the Image $\mathrm{J}$ software (http://rsb.info.nih.gov/ij/docs/index.html).

Flow cytometric analysis (annexin V-FITC/propidium iodide staining) of phosphatidylserine exposure. At the indicated times and doses of treatment, K562, U937 and Jurkat cells were assayed for phosphatidylserine exposure, by using the Annexin V-FITC Apoptosis Detection Kit I (Becton Dickinson Biosciences, Erembodegem, Belgium) according to the manufacturer's instructions. Stained samples were analyzed by FACS (FACSCalibur, Becton Dickinson, San Jose, CA, USA). Data were recorded using the CellQuest software (http://www.bdbiosciences.com/features/products) for further analysis.

\subsection{Extraction of cellular proteins}

After indicated incubation times with UNBS1450 and TNFa, K562, U937 and Jurkat cells were lysed; nuclear and cytoplasmic extracts were prepared according to [10].

\subsection{RT-PCR Analysis}

Isolation of total RNA was performed using a NucleoSpin ${ }^{\circledR}$ (Macherey-Nagel, Hoerdt, France) kit. $1 \mu \mathrm{g}$ of total RNA were submitted to reverse transcription (RT) using Oligo(dT) primers (SuperScript First-Strand Synthesis System, Invitrogen, Fisher Scientific, Tournai, Belgium). The resulting RT products were used as templates for PCR amplification using SYBR ${ }^{\circledR}$ Green (Power SYBR Green PCR Master mix 1X, Applied Biosystems, Halle, Belgium) and $\mathrm{Na}^{+} / \mathrm{K}^{+}$-ATPase $\alpha$-subunit mRNA specific primers (F : 5'-CTA-CCT-GGCTTG-CTC-TGT-CC-3'; R : 5'-GCT-GAC-TCA-GAG-GCA-TCT-CC-3') (Eurogentec, Liège, Belgium). The amount of cDNA synthesized was evaluated by amplification of the GAPDH gene (F : 5'-ACA-GTC-AGC-CGC-ATC-TTC-TT-3' ; R : 5'-ACG-ACC-AAA-TCC-GTTGAC-TC-3') (Eurogentec, Liège, Belgium) as a standard. After amplification, the PCR products were separated on a $2 \%$ agarose gel.

\subsection{Western Blot analysis}


Proteins of total extracts were separated by size using sodium dodecyl sulfate polyacrylamide gel electrophoresis (SDS-PAGE, $10 \%$ ), transferred onto nitrocellulose membranes and blocked with $5 \%$ non-fat milk in phosphate buffered saline (PBS)-Tween overnight. Equal loading of samples was controlled using $\beta$-actin or lamin B and $\alpha$-tubulin for cytosolic and nuclear extracts.

Blots were incubated with primary antibodies: anti-pIкB $\alpha$ (1/3000, Cell Signaling 9246, Bioké, Leiden, Netherlands), anti-IкB $\alpha$ (1/500, Santa Cruz SC-371, Tebu-Bio, Boechout, Belgium), anti-p50 (1/5000, Santa Cruz SC-7178X), anti-p65 (1/5000, Santa Cruz SC-8008), anti- $\alpha$-tubulin (1/5000, Calbiochem CP06, VWR, Leuven, Belgium), anti-lamin- $\beta$ (1/1000, Santa Cruz SC-6216), anti- $\beta$-actin (1/10000, Sigma-Aldrich A5441, Bornem, Belgium), anti-caspase-3 (1/5000, Cell Signaling 9668), anti-caspase-7 (1/1000, Cell Signaling 9494), anti-caspase-8 (1/1000, Cell Signaling 9746), anti-caspase-9 (1/1000, Cell Signaling 9502), anti-XIAP (1/1000, BD Pharmingen 610763, Erembodegem, Belgium), antiBcl-2 (1/2000, Calbiochem OP60) and anti-Mcl-1 (1/1000, Cell Signaling 4572). All antibodies were diluted in a PBS-Tween solution containing $5 \%$ of bovine serum albumin (BSA) or $5 \%$ of milk according to the providers' protocols. After incubation with primary antibodies, membranes were washed $3 \times 10$ min with PBS-Tween, followed by an incubation of $1 \mathrm{~h}$ at RT with the corresponding secondary (HRP-conjugated) antibodies. After washing 3 $\mathrm{x} 10 \mathrm{~min}$ with $\mathrm{PBS}-$ Tween, specific immunoreactive proteins were visualized by autoradiography using the ECL Plus Western Blotting Detection System Kit ${ }^{\circledR}$ (GE Healthcare, Roosendaal, Netherlands).

\subsection{Elisa}

IL-8 concentrations in culture supernatants of activated K562, U937 and Jurkat cells were measured by sandwich ELISA (R\&D Systems, Abingdon, United Kingdom). According to the manufacturer's guide, $50 \mu \mathrm{L}$ of cell supernatants were added together with $100 \mu \mathrm{L}$ of Assay Diluent to anti-IL-8 pre-coated wells, followed by $2 \mathrm{~h}$ of incubation at RT. After washing, a polyclonal peroxydase-conjugated anti-IL-8 antibody was added for another 60 min at RT. Colorimetric visualization and protein dosage were rendered possible by addition of the $\mathrm{H}_{2} \mathrm{O}_{2}$ and TMB (tetramethylbenzidine) containing substrate. After 30 min of reaction at $\mathrm{RT}$, in the dark, the enzymatic reaction was stopped by $\mathrm{H}_{2} \mathrm{SO}_{4}$ and optical densities were measured at a wavelength of $450 \mathrm{~nm}$. 


\section{Results}

\subsection{UNBS1450 induces apoptosis in human leukemia cells}

We first evaluated the effect of UNBS1450 on the cell growth of chronic myeloid leukemia K562, histiocytic lymphoma U937 and acute T-cell leukemia Jurkat human leukemia. Cells were treated for 24, 48 and 72h with different concentrations of UNBS1450 and their culture concentrations estimated by Trypan Blue exclusion assay. As reported in Figure 1B, UNBS1450 deeply affected cell growth in a dose-dependent manner with an $\mathrm{IC}_{50}$ value of $13.37 \pm 2.1 \mathrm{nM}$ in $\mathrm{U} 937$.

To disentangle whether the effects of UNBS1450 were due to an impact on cell viability rather than an effect on cell metabolism and, therefore growth, we performed at first a cell cycle analysis to detect and quantify the presence of any sub-G1 phase. The analysis reported in Figure 1C showed that UNBS1450 lead to accumulation of cells in a sub-G1 phase in a dose-dependent manner, significantly starting from $15 \mathrm{nM}$, thus confirming that UNBS1450 induced cell death. From 20nM to 30nM, UNBS1450 increasingly drove U937 cells into a sub-G1 phase (Figure 1C).

Next, we investigated the nature of cell death induced by UNBS1450, first by analyzing alterations in cell morphology by Hoechst staining and fluorescence microscopy (Figure 1D, top). As shown, the nuclei of U937 cells treated with UNBS1450 underwent morphological alterations typically occurring during apoptosis [11]. Figure 1D (bottom) shows the quantification of apoptosis after UNBS1450 treatment, as estimated by counting the fraction of cells stained with Hoechst and presenting fragmented nuclei. Annexin V/PI double staining confirmed apoptotic cell death (Figure 1E) starting from $15 \mathrm{nM}$, thus giving similar results to Hoechst analysis.

In order to generalize our effects, we used K562 cells and observed similar findings. Again, UNBS1450 reduced cell proliferation in a dose- and time-dependent manner with an $\mathrm{IC}_{50}$ value of $32.65 \pm 3.10 \mathrm{nM}$ at $48 \mathrm{~h}$ (Supplemental Figure 1A). Cell cycle analysis (Supplemental Figure 1B) showed that an incubation time of $48 \mathrm{~h}$ in the presence of UNBS1450 50nM drove a fraction of cells into a sub-G1 phase while overall cell status remained rather unchanged; G1 and G2/M phases still showed control-comparable patterns. Hoechst staining indicated fragmented cell nuclei of cells dying via apoptosis (Supplemental Figure 1C). FACS analysis for the exposure of phosphatidylserine/plasma membrane integrity by annexin V/PI analysis confirmed the activation of an apoptotic program 
(Supplemental Figure 1D). Similar effects of UNBS1450 on cell death induction were observed in Jurkat T cells (Supplemental Figures 2A and B).

Concerning the specificity of UNBS1450 for cancer cells, we further analyzed the effects of UNBS1450 on normal, healthy PBMCs (Figure 1F). After 24 h of incubation time, PBMCs had been treated by various concentrations of UNBS1450 (0-100 nM) for $24 \mathrm{~h}$. Sample volumes were then divided: Trypan Blue staining was performed to assess cell integrity (upper panel) whereas Hoechst staining allowed determination of apoptotic percentages (lower panel). Altogether, UNBS1450 did not change cell permeability to Trypan Blue thus allowing us to conclude that cell viability of PBMCs is not compromised by UNBS1450. These results were confirmed by quantification of apoptotic cells: only a weak effect was observed at $100 \mathrm{nM}(\leq 16 \%)$ which was not comparable to what we obtained in leukemia cell lines (> $60 \%$ for UNBS1450 at $30 \mathrm{nM}$ in U937; Figure 1D).

As it has been shown that the $\alpha 1$ subunit of $\mathrm{Na}+\mathrm{K}+-\mathrm{ATPases}$ is a target for UNBS1450 [2] and that it is frequently overexpressed in solid tumor cells where UNBS1450 is severely inhibiting proliferation [2], we compared $\alpha 1$ subunit mRNA expression levels of a panel of hematological cancer cell lines to those of normal healthy PBMCs (Figure 2). Our results indicate all cell lines express the corresponding mRNA but that only K562 produces significantly higher amounts compared to PBMCs $\left(2^{\wedge} \Delta \mathrm{Ct}\right.$ values of 0.06 versus 0.011 respectively, \pm S.D.). For all other cell lines, subunit $\alpha 1$ specific mRNA levels were not significantly different compared to PBMCs.

\subsection{Effect on anti-apoptotic cell signaling pathways}

We subsequently investigated whether UNBS1450 was able to trigger a caspasedependent apoptotic cell death (Figure 3A). To this purpose, a kinetic analysis (0h to $24 \mathrm{~h}$ ) was performed on U937 cells treated with UNBS1450 at 20nM. We demonstrated that UNBS1450 at 20nM induced the cleavage of the pro-caspases-9 and -8 starting after $12 \mathrm{~h}$ of incubation time. The executor pro-caspases-3 and-7, substrates of caspase-9, were cleaved into active caspase-3 and 7 (Figure 3A).

Induction of apoptosis can be triggered by both inhibition of anti-apoptotic- and/or by activation of pro-apoptotic mechanisms. Here, overall expression of XIAP and Bcl-2 were not influenced by UNBS1450 (Figure 3B). The expression level of Mcl-1 however, another antiapoptotic Bcl-2 family member, was sensibly affected by the treatment with UNBS1450 as a 
strong reduction in the protein level was noticeable after $4 \mathrm{~h}$ of treatment while after $12 \mathrm{~h}$ of treatment, no expression level was detectable anymore.

\subsection{Activation of pro-apoptotic mechanisms}

We then analyzed in situ the activation status of pro-apoptotic Bak and Bax in U937 cells, untreated and treated with 10 to $30 \mathrm{nM}$ of UNBS1450, by using antibodies specifically recognizing activated forms of both pro-apoptotic Bcl-2 family members. Immunostained cells were counterstained with Hoechst to detect apoptotic nuclei. Bak resulted activated by treatments with $15 \mathrm{nM}$ UNBS1450 and higher (Figure 4A). Similar results were observed for activated Bax (Bax6A7) (Figure 4B). As expected, both activated Bak and Bax co-localized with cells presenting fragmented, apoptotic nuclei, witnessing apoptotic cell death triggered by UNBS1450 a semi-synthetic cardenolide originally from the plant Calotropis Procera.

\subsection{Inhibition of NF- $\kappa \mathrm{B}$ pathway activation}

$\mathrm{NF}-\kappa \mathrm{B}$ transcription factor is well known to act as an inhibitor of apoptotic cell signaling specifically via transactivation. Moreover Mijatovic et al. [12] already provided first insights into UNBS1450-induced inhibition of NF-kB activation. Here we observed that UNBS1450 reduced TNF $\alpha$-driven NF- $\mathrm{BB}$ activation in a dose-dependent manner in K562 and Jurkat cells (Figure 5A and B). As illustrated in Table I, UNBS1450 has however no repressing effect on constitutive, basal NF- $\mathrm{kB}$ activity in K562 cells.

In order to further confirm the inhibitory effect of UNBS1450 on the TNF $\alpha$-induced NF- $\kappa B$ signaling pathway, we realized EMSA. Figure 5C clearly shows that at a concentration of UNBS1450 $40 \mathrm{nM}$ inhibits TNF $\alpha$-induced NF- $\mathrm{kB}-\mathrm{DNA}$ binding. By applying various pre-treatment times from 0 to $16 \mathrm{~h}$, we obtained a complete inhibition after 8 $\mathrm{h}$ of pre-incubation. Incubation with p50 and p65 antibodies enabled us to identify the NF- $\mathrm{B}$ dimer composition as p50 and p65. Similar results were obtained for Jurkat cells (Figure 5D).

$\mathrm{NF}-\kappa \mathrm{B}$ activation is generally initiated by the degradation of its natural inhibitor $\mathrm{I} \kappa \mathrm{B} \alpha$; we thus assessed I $\mathrm{K} \mathrm{B} \alpha$ integrity as well as the translocation of p65 from the cytoplasm to the nucleus by Western Blot analysis (Figure 5E). Both degradation of $\mathrm{I} \kappa \mathrm{B} \alpha$ as well as translocation of p65 into the nucleus, were analyzed by Western Blot. In control cells without UNBS1450 pre-treatment, I $\mathrm{KB} \alpha$ degradation was observed after $10 \mathrm{~min}$ of TNF $\alpha$ stimulation; consequently, p65 translocation to the nucleus was observed in parallel. In contrast, the presence of UNBS1450 inhibited $\mathrm{TNF} \alpha$-induced degradation of $\mathrm{I} \kappa \mathrm{B} \alpha$ and considerably prevented the translocations of p65 into the nucleus (Figure 5E, right panel). 


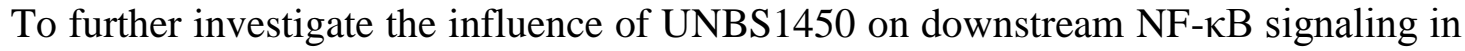
K562, U937 and Jurkat cells, we chose IL-8 as it was described that this gene product is under the control of NF- $\mathrm{KB}$. We observed that UNBS1450-pre-treated cells produced significantly lower quantities of IL-8 (less than $600 \mathrm{pg} / \mathrm{mL}$ ) compared to TNF $\alpha$ only activated K562 cells (1300 pg/mL) (Figure 5F). Similar results were obtained for U937 (Figure 5G). Unstimulated U937 cells produced low amounts of IL-8 (92 pg/mL) and TNFa activation resulted in increased IL-8 release $(1002 \mathrm{pg} / \mathrm{mL})$. A significant inhibition was obtained after UNBS1450 treatment at $20 \mathrm{nM}$ (IL-8 release: $721 \mathrm{pg} / \mathrm{mL}$ ). In Jurkat cells, TNFạstimulation could not trigger IL-8 release; neither did UNBS1450 show any significant effect on IL-8 release (results not shown). 


\section{Discussion}

We show here that UNBS1450, belonging to the cardenolide family of the steroid cardiac glycosides, efficiently reduces viability of leukemia cancer cell lines by inducing apoptotic cell death. We focused our efforts on possible modifications of inflammation and cell death induction by UNBS1450. To this purpose, we used chronic myeloid leukemia K562, histiocytic lymphoma U937 as well as acute T-cell leukemia Jurkat cells stimulated by $\mathrm{TNF} \alpha$ as a model of investigation to mimic pro-inflammatory surroundings stimulating the $\mathrm{NF}-\kappa \mathrm{B}$ transcription factor.

While UNBS1450 has so far mainly been applied on solid tumors [1] [12], we hereby confirm that deactivation of NF- $\mathrm{KB}$ activity through UNBS1450 is also true in human leukemia cells as indicated by reduced induction of NF- $\mathrm{\kappa B}$ transcriptional activity, reduced binding to target DNA as well as repressed synthesis of NF- $\mathrm{kB}-$ dependent genes. TNF $\alpha$ induced p50/p65 dimer translocation to the nucleus is strongly reduced in the presence of UNBS1450 due to repressed IKB $\alpha$ degradation.

We also analyzed the impact of UNBS1450 on leukemia cell survival capacity. As finally indicated by increased Annexin V/PI staining, fragmented nuclei after Hoechst staining and thus reduced cell numbers, UNBS1450 is beneficial to an apoptosis induction. We observed that nanomolar concentrations of UNBS1450 were able to induce the cleavages of the initiator caspases 8 and 9 as shown by Western Blot. Furthermore, we obtained a cleavage induction of the pro-caspase-7, leading to hypothetic thoughts that UNBS1450 might induce apoptosis by processing and concomitant activation of effector caspases such as caspase-7 and caspase-3. Consequently, we assessed expression levels of various Bcl-2 family proteins in order to conclude on a possible amplification of the death signal through activation of the intrinsic mitochondrial cell death pathways [13] [14]. The analysis of cell proliferation in the presence of UNBS1450 in both cell lines investigated reveals that the compound is able to affect cell proliferation at concentrations lower than those requested to induce apoptosis (see Figure 1B and supplemental Figure 1A). This is in line with previous findings [15] and prompts to elucidate in the future whether this cytostatic potential may be also implicated in determining the cytotoxic effect.

Several studies underline their pivotal role [16] in apoptosis induction [17, 18] [19]. Loss of expression as well as over-expression of Bcl-2 family genes, depending on the pro- or anti-apoptotic potential, can lead to oncogenesis by decreased malignant cell death. It is for instance known that over-expression of anti-apoptotic Bcl-2 or Mcl-1 disables apoptosis 
induced by TNF-related ligands [20] [21] [22]. Consequently, we assessed by Western Blot the expression levels of XIAP, a member of the inhibitor of apoptosis family, and Bcl-2 as well as Mcl-1, each a member of the anti-apoptotic Bcl-2 subfamily. Whereas expression levels remained unaltered for XIAP and Bcl-2 in the presence of UNBS1450, Mcl-1 was found to be strongly down-regulated by UNBS1450. Combined to the fact that noticeably low concentration levels in a nanomolar range were largely sufficient to influence the expression of Mcl-1 in the observed manner suggests this anti-apoptotic protein may play a major role in apoptosis induction due to UNBS1450.

Mcl-1 acts by directly binding to Bak and Bax proteins that are two pro-apoptotic Bcl2 family members. From the perspective of the Bcl-2 family proteins, the intrinsic apoptosis pathway is initiated by various signals. BH3-only proteins such as Bim, Bid, Bad, Noxa or Puma engage with anti-apoptotic members such as Mcl-1 to relieve inhibition of Bak and Bax as reviewed by Kang and Reynolds [23]. Direct or indirect repression of Mcl-1 expression results in Bak and Bax activation and oligomerisation eventually leading to mitochondrial outer membrane permeabilisation and cell death through apoptosis [24]. Our results strongly suggest this pathway to be stimulated by UNBS1450 in human leukemia cell lines. Further point-by-point investigations are necessary to elucidate the exact molecular cascades closing the gap between $\mathrm{Na}^{+} / \mathrm{K}^{+}$-ATPase binding of UNBS1450 and Mcl-1 expression inhibition and thus apoptosis induction.

Today, NF- $\mathrm{KB}$ is considered by most as a key anti-apoptotic factor [25, 26]. Besides frequent constitutive expression of $\mathrm{NF}-\mathrm{\kappa B}$ in various human cancer cell lines, contributing to the onset of drug resistance of tumor cells or to increased aggressiveness [27] [28] [29], it is well documented nowadays that $\mathrm{TNF} \alpha$ release by the tumor microenvironment is a characteristic of many malignant tumors and acts as a sort of a master switch between activation of inflammatory processes and oncogenesis [8] [30]. Through its receptors both on epithelial and stromal cell membranes, TNF $\alpha$ either directly influences cell proliferation and malignant cell survival or indirectly drives surrounding stromal cells, macrophages, dendritic cells and fibroblasts into releasing general inflammatory cytokines such as TNF $\alpha$ itself, IL-1, IL-6 and IL-8 [31]. Altogether, this creates a beneficial situation for the onset of genetic alterations and enhanced survival and proliferation of the tumor cells.

As a conclusion, we hereby further described the mechanism by which UNBS1450 inhibits tumor expansion by cell death induction. As an addition to existing knowledge of anti-cancer activities of UNBS1450 due to autophagy [4] [5] mainly on human glioblastoma and NSCLC, we demonstrate here that this semi-synthetic cardenolide rapidly and effectively 
induces cell death through apoptosis in human leukemia cell lines. While down-regulating induced NF- $\kappa$ B pathway, UNBS1450 activates the extrinsic caspase-dependent apoptotic pathway, represses the expression of Mcl-1, activating pro-apoptotic Bak and Bax and eventually leading to cell death via the mitochondrial apoptotic pathway. However, we do not have obvious evidence that a downregulation of the NF-kB pathway is linked to the observed induction of apoptosis as UNBS1450 does not show any inhibitory activities on constitutive $\mathrm{NF}-\kappa \mathrm{B}$ activity in K562 cells where induced apoptosis is significant.

While additional analysis thus remain requested to further analyze signaling cascades involved, these findings show for the first time that UNBS1450 acts as an apoptogenic inducer, specifically affecting cancer cell lines. This makes of UNBS1450 a promising candidate as a new potential anti-cancer drug for leukemia and lymphoma treatments. 


\section{Acknowledgments}

This work was supported by Télévie, the "Fondation de Recherche Cancer et Sang" and "Recherches Scientifiques Luxembourg" asbl. TJ is the recipient of an AFR grant (Fonds National de la Recherche Luxembourg). CC, FM, MT and MS were supported by Télévie grants (Fonds National de la Recherche Scientifique, Belgium). The authors thank "Een Häerz fir Kriibskrank Kanner" association and the Action Lions "Vaincre le Cancer" for generous support. Further support was received from the Foundation for Scientific Cooperation between Germany and Luxemburg and the European Union (ITN "RedCat" 215009 and Interreg IVa project "Corena"). Print costs were covered by the Fonds National de la Recherche (FNR), Luxembourg. 


\section{Legends to Figures}

Figure 1: UNBS1450 induces apoptotic cell death in U937 cells. A. Molecular structure. B. Analysis of UNBS1450-induced cell death was performed by trypan blue staining after 24, 48 and $72 \mathrm{~h}$ of treatment with UNBS1450 at 10, 15, 20 and 30nM. C. Cell cycle analysis after $24 \mathrm{~h}$ of incubation time with indicated concentrations, D. Hoechst staining (upper panel) and quantification (lower panel) of the fraction of cells presenting fragmented nuclei. E. Flow cytometry analysis after $24 \mathrm{~h}$ of incubation time at indicated concentrations. F. Analysis of PBMCs viability after UNBS1450 treatment. PBMCs were seeded at $2 * 10^{6}$, then after $24 \mathrm{~h}$ treated for $24 \mathrm{~h}$ with various concentrations $(0-100 \mathrm{nM})$ of UNBS1450. Cells were then either stained by Trypan Blue (upper panel) or by Hoechst (panel below) to either analyze cell integrity or apoptosis induction. The data shown here were representative for three independent experiments.

Figure 2. $\mathrm{Na}^{+} / \mathrm{K}^{+}$-ATPase subunit $\alpha 1 \mathrm{mRNA}$ quantification. $\mathrm{Na}^{+} / \mathrm{K}^{+}$-ATPase subunit $\alpha 1$ mRNA content of untreated PBMCs and a wide panel of hematological cancer cell lines including K562, Jurkat and U937 cells was transcribed and then quantified by RT-PCR. The quantification of three independent experiments is expressed in brute $2^{\wedge} \Delta \mathrm{Ct}$ values +- S.D.

Figure 3. A. Caspase activation. U937 cells were incubated in RPMI+10\% FCS \pm UNBS1450 20nM up to $24 \mathrm{~h}$. Western Blot analysis of UNBS1450-induced cleavage of procaspases-9, -8, -7 and -3. B. Analysis of expression levels of anti-apoptotic proteins. UNBS1450-induced expression level alterations of XIAP, Bcl-2 and Mcl-1. The data shown here were representative for three independent experiments.

Figure 4. UNBS1450 enables Bak/Bak activation. U937 cells were incubated for $24 \mathrm{~h}$ in RPMI+10\% FCS in presence or in absence of UNBS1450. Bak (A.) and Bax (B.) activation status were assessed by using primary antibodies specifically targeting activated forms of Bak (Ab-1; Calbiochem) and Bax (6A7; Santa Cruz). Counterstaining was done by Hoechst staining to assess apoptotic nuclei. The data shown here were representative for three independent experiments with similar results.

Figure 5. Inhibition by UNBS1450 of TNF $\alpha$-induced NF-kB activation. A. K562 and B. Jurkat cells were pretreated with UNBS1450 at various concentrations from 10-50 nM and 
incubated for 2 hours, followed by TNF $\alpha$ addition $(20 \mathrm{ng} / \mathrm{ml})$ and an additional incubation period of 6 hours. Results are represented as the ratio of the measured luminescence of the firefly luciferase vector divided by the measured luminescence of the Renilla plasmid. Untreated cells were used as a negative control, cells treated with TNF $\alpha$ only as a positive control. Results are presented as mean $\pm \mathrm{SD}$ of 3 individual measurements performed in triplicates. C. Effect of UNBS1450 on the binding affinity of NF- $\kappa \mathrm{B}$ was assessed by an EMSA on the K562 and Jurkat cell line. The data shown here were representative for three independent experiments with similar results. D. For supershift/immunodepletion experiments, the nuclear extracts and labeled probes were incubated in the reaction mixture for $30 \mathrm{~min}$ on ice prior to a $30 \mathrm{~min}$ incubation with $2 \mu \mathrm{g}$ of anti-p50 or anti-p65, antibodies. SS designates supershifted bands. E. Jurkat cells were incubated with UNBS1450 (40 nM) for 2 hours, followed by a TNF $\alpha(20 \mathrm{ng} / \mathrm{ml})$ activation for the indicated time periods. Cytoplasmic and nuclear extracts were prepared, fractionated on a $10 \%$ SDS-page gel, transferred to a membrane and then tested for I $\kappa \mathrm{B} \alpha$ and $\mathrm{p} 65$. Protein loading and purity of nuclear/cytosolic extracts were verified by lamin B and $\alpha$-tubulin Western Blots. Data shown are representative for three independent experiments with similar results. K562 (F.), and U937 (G.) cells were incubated for $2 \mathrm{~h}$ in RPMI $+10 \%$ FCS in presence or in absence of various concentrations (10-50 nM) of UNBS1450 before being activated by TNF $\alpha$ during 22 h. After $24 \mathrm{~h}$ of incubation IL-8 concentrations in supernatants were measured. Untreated cells served as negative control whereas cells activated by TNF $\alpha$ only were used as a positive control. The data shown here were representative for three independent experiments with similar results. 


\section{Legends to Supplemental Figures}

Supplemental Figure 1: UNBS1450 induces apoptotic cell death in K562 cells. A. Analysis of UNBS1450-induced cell death was performed by trypan blue staining after 24, 48 and $72 \mathrm{~h}$ of treatment with UNBS1450 at 10, 30 and 50nM. B. Cell cycle analysis after 48h of incubation time at indicated concentrations, C. Hoechst staining and D. quantification of the fraction of cells presenting fragmented nuclei. E. Flow cytometry analysis after $48 \mathrm{~h}$ of incubation time at indicated concentrations.

Supplemental Figure 2: UNBS1450 induces apoptotic cell death in Jurkat cells. A. Analysis of UNBS1450-induced cell death was performed by trypan blue staining after 24, 48 and $72 \mathrm{~h}$ of treatment with UNBS1450 at 10,30 and 50nM. B. Cell cycle analysis after 24h of incubation time with indicated concentrations. 


\section{References}

[1] Mijatovic T, Lefranc F, Van Quaquebeke E, Van Vynckt F, Darro F, Kiss R. UNBS1450 : A New Hemi-Synthetic Cardenolide With Promising Anti-Cancer Activity. Drug Development Research 2007;68:164-73.

[2] Lefranc F, Mijatovic T, Kondo Y, Sauvage S, Roland I, Debeir O, et al. Targeting the alpha 1 subunit of the sodium pump to combat glioblastoma cells. Neurosurgery 2008;62:211-21; discussion 21-2.

[3] Juncker T, Schumacher M, Dicato M, Diederich M. UNBS1450 from Calotropis procera as a regulator of signaling pathways involved in proliferation and cell death. Biochem Pharmacol 2009;78:1-10.

[4] Mijatovic T, Mathieu V, Gaussin JF, De Neve N, Ribaucour F, Van Quaquebeke E, et al. Cardenolide-induced lysosomal membrane permeabilization demonstrates therapeutic benefits in experimental human non-small cell lung cancers. Neoplasia 2006;8:402-12.

[5] Mijatovic T, De Neve N, Gailly P, Mathieu V, Haibe-Kains B, Bontempi G, et al. Nucleolus and c-Myc: potential targets of cardenolide-mediated antitumor activity. Mol Cancer Ther 2008;7:1285-96.

[6] Lefranc F, Mijatovic T, Kiss R. [The sodium pump could constitute a new target to combat glioblastomas]. Bull Cancer 2008;95:271-81.

[7] Perkins ND. Integrating cell-signalling pathways with NF-kappaB and IKK function. Nat Rev Mol Cell Biol 2007;8:49-62.

[8] Balkwill F. Tumour necrosis factor and cancer. Nat Rev Cancer 2009;9:361-71.

[9] Coppola S, Ghibelli L. GSH extrusion and and the mitochondrial pathway of apoptotic signalling. Biochem Soc Trans 2000;28:56-61.

[10] Duvoix A, Delhalle S, Blasius R, Schnekenburger M, Morceau F, Fougere M, et al. Effect of chemopreventive agents on glutathione S-transferase P1-1 gene expression mechanisms via activating protein 1 and nuclear factor kappaB inhibition. Biochem Pharmacol 2004;68:1101-11.

[11] Cerella C, Scherer C, Cristofanon S, Henry E, Anwar A, Busch C, et al. Cell cycle arrest in early mitosis and induction of caspase-dependent apoptosis in U937 cells by diallyltetrasulfide (A12S4). Apoptosis 2009;14:641-54.

[12] Mijatovic T, Op De Beeck A, Van Quaquebeke E, Dewelle J, Darro F, de Launoit Y, et al. The cardenolide UNBS1450 is able to deactivate nuclear factor kappaBmediated cytoprotective effects in human non-small cell lung cancer cells. Mol Cancer Ther 2006;5:391-9.

[13] Daniel PT, Wieder T, Sturm I, Schulze-Osthoff K. The kiss of death: promises and failures of death receptors and ligands in cancer therapy. Leukemia 2001;15:1022-32.

[14] Kaufmann SH, Steensma DP. On the TRAIL of a new therapy for leukemia. Leukemia 2005;19:2195-202.

[15] Mijatovic T, Roland I, Van Quaquebeke E, Nilsson B, Mathieu A, Van Vynckt F, et al. The alpha1 subunit of the sodium pump could represent a novel target to combat non-small cell lung cancers. J Pathol 2007;212:170-9.

[16] Lomonosova E, Chinnadurai G. BH3-only proteins in apoptosis and beyond: an overview. Oncogene 2008;27 Suppl 1:S2-19.

[17] Bouillet P, Metcalf D, Huang DC, Tarlinton DM, Kay TW, Kontgen F, et al. Proapoptotic Bcl-2 relative Bim required for certain apoptotic responses, leukocyte homeostasis, and to preclude autoimmunity. Science 1999;286:1735-8. 
[18] Arena V, Martini M, Luongo M, Capelli A, Larocca LM. Mutations of the BIK gene in human peripheral B-cell lymphomas. Genes Chromosomes Cancer 2003;38:91-6.

[19] Bouillet P, Strasser A. BH3-only proteins - evolutionarily conserved proapoptotic Bcl2 family members essential for initiating programmed cell death. J Cell Sci 2002;115:1567-74.

[20] Henson ES, Gibson EM, Villanueva J, Bristow NA, Haney N, Gibson SB. Increased expression of Mcl-1 is responsible for the blockage of TRAIL-induced apoptosis mediated by EGF/ErbB1 signaling pathway. J Cell Biochem 2003;89:1177-92.

[21] Taniai M, Grambihler A, Higuchi H, Werneburg N, Bronk SF, Farrugia DJ, et al. Mcl1 mediates tumor necrosis factor-related apoptosis-inducing ligand resistance in human cholangiocarcinoma cells. Cancer Res 2004;64:3517-24.

[22] Zhang XD, Nguyen T, Thomas WD, Sanders JE, Hersey P. Mechanisms of resistance of normal cells to TRAIL induced apoptosis vary between different cell types. FEBS Lett 2000;482:193-9.

[23] Kang MH, Reynolds CP. Bcl-2 inhibitors: targeting mitochondrial apoptotic pathways in cancer therapy. Clin Cancer Res 2009;15:1126-32.

[24] Spierings D, McStay G, Saleh M, Bender C, Chipuk J, Maurer U, et al. Connected to death: the (unexpurgated) mitochondrial pathway of apoptosis. Science 2005;310:667.

[25] Gilmore TD. Introduction to NF-kappaB: players, pathways, perspectives. Oncogene 2006;25:6680-4.

[26] Reuter S, Eifes S, Dicato M, Aggarwal BB, Diederich M. Modulation of antiapoptotic and survival pathways by curcumin as a strategy to induce apoptosis in cancer cells. Biochem Pharmacol 2008;76:1340-51.

[27] Karin M, Greten FR. NF-kappaB: linking inflammation and immunity to cancer development and progression. Nat Rev Immunol 2005;5:749-59.

[28] Ahn KS, Sethi G, Aggarwal BB. Reversal of chemoresistance and enhancement of apoptosis by statins through down-regulation of the NF-kappaB pathway. Biochem Pharmacol 2008;75:907-13.

[29] Wu Y, Zhou BP. TNF-alpha/NF-kappaB/Snail pathway in cancer cell migration and invasion. Br J Cancer 2010;102:639-44.

[30] Mantovani A. Cancer : Inflaming metastasis. Nature 2009:36-7.

[31] Sethi G, Sung B, Aggarwal BB. TNF: a master switch for inflammation to cancer. Front Biosci 2008;13:5094-107. 

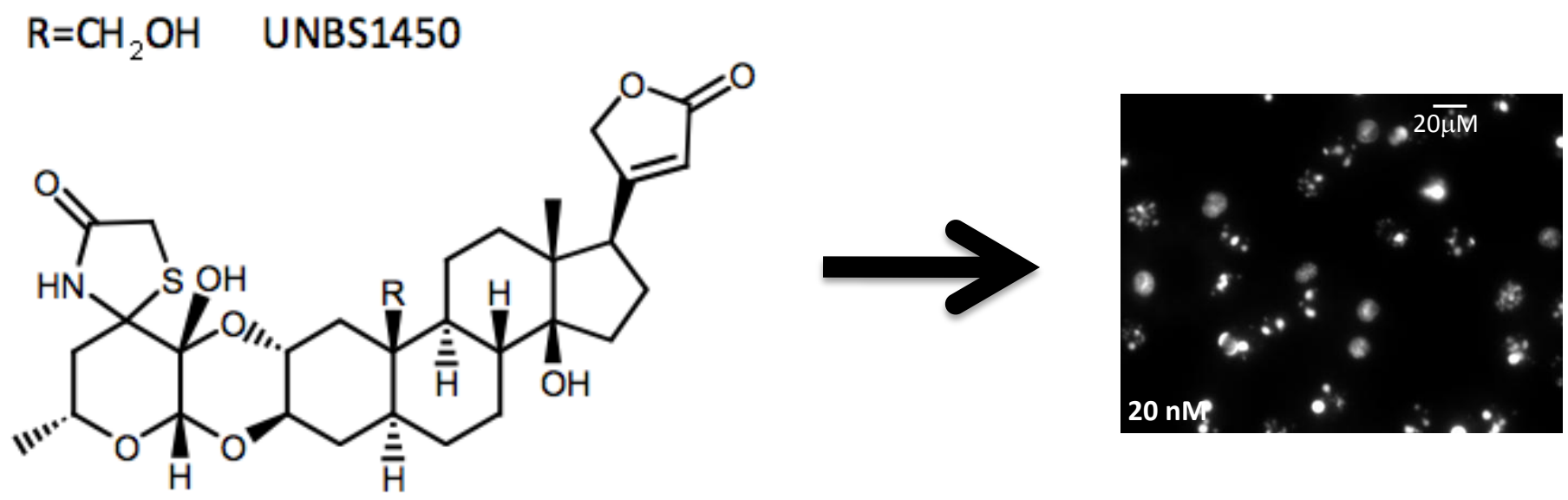
Table I. Effect of UNBS1450 (40 nM) on basal and TNF $\alpha$-induced NF-kB activity.

\begin{tabular}{lcc}
\hline K562 & R.L.A. (\%) & S.D. (\%) \\
\hline untreated & 0.574 & 0.147 \\
UNBS1450 (40 nM) & 0.587 & 0.178 \\
TNF $\alpha$ & 100 & 2.850 \\
UNBS1450 (40 nM) + TNF $\alpha$ & 42.578 & 7.761 \\
\hline
\end{tabular}


A.

$\mathrm{R}=\mathrm{CH}_{2} \mathrm{OH} \quad$ UNBS1450

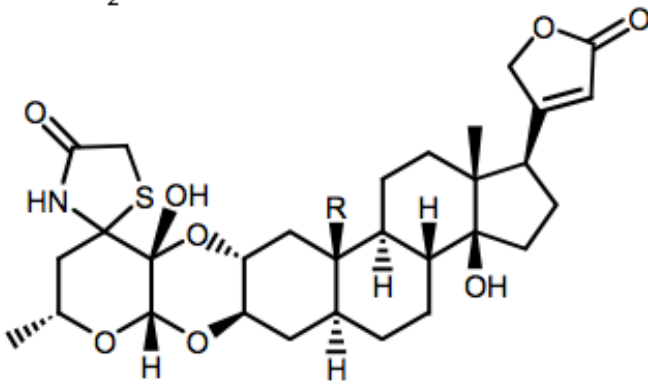

B.

Control $\square 10 \mathrm{nM} \square 15 \mathrm{nM} \square 20 \mathrm{nM} \square 30 \mathrm{nM}$

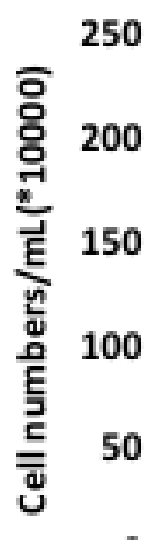

C. 0

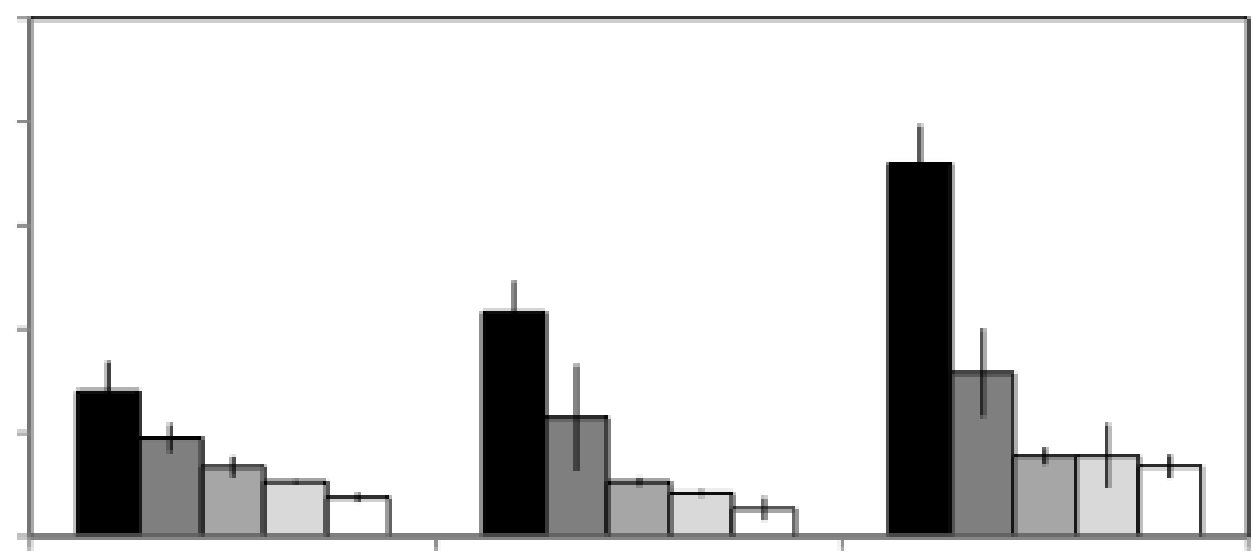

24h

$48 \mathrm{~h}$

72h
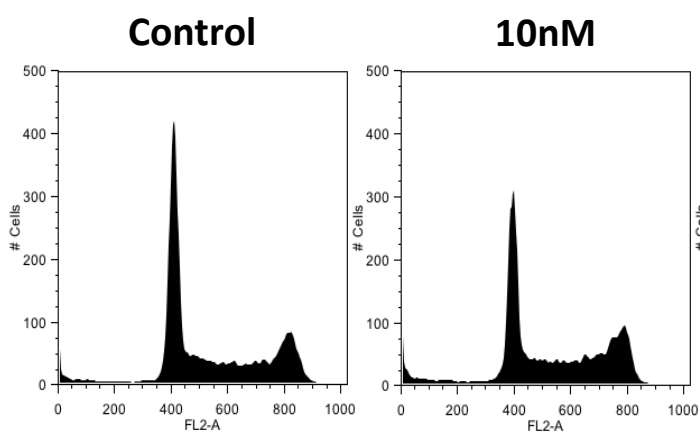

$15 \mathrm{nM}$

20nM

30nM
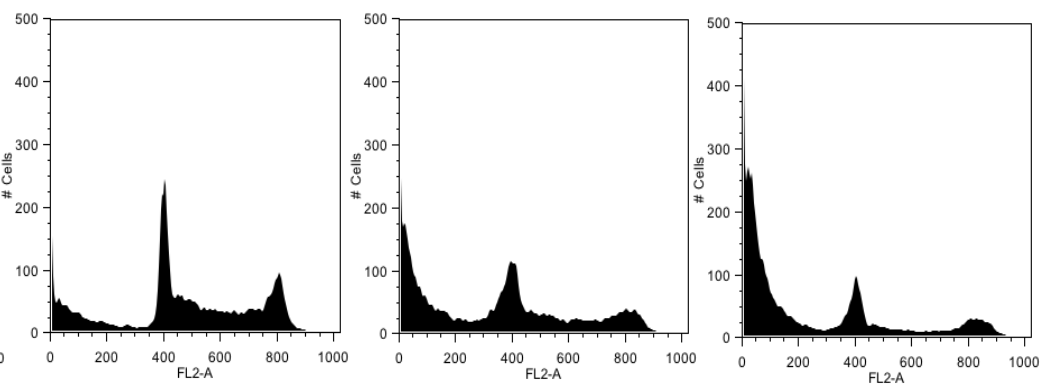

口subG1 $\square \mathrm{G1}$ 口S $\square \mathrm{G2} / \mathrm{M}$

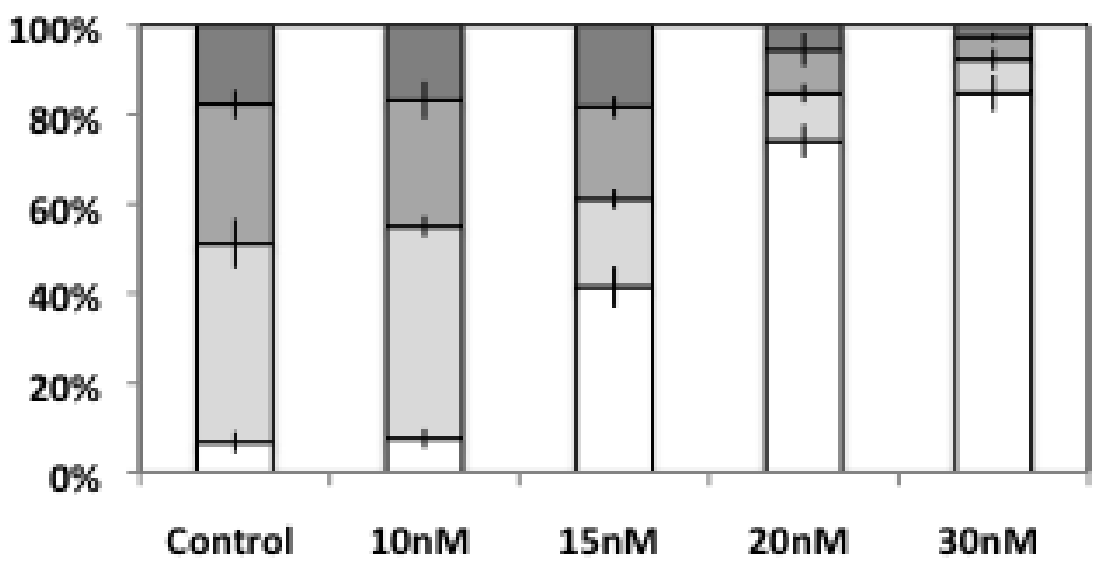

Figure 1 
D.
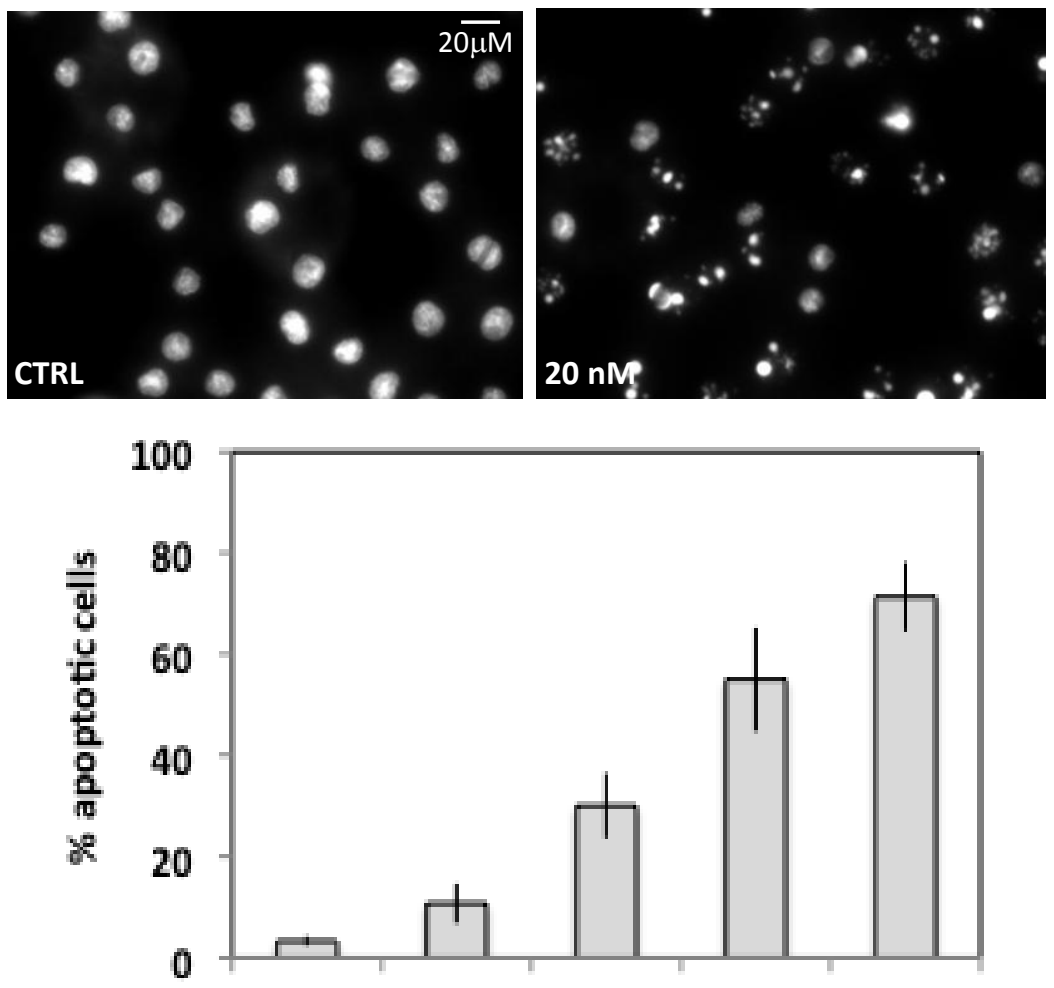

Control $10 \mathrm{nM} \quad 15 \mathrm{nM} \quad 20 \mathrm{nM} \quad 30 \mathrm{nM}$

E.
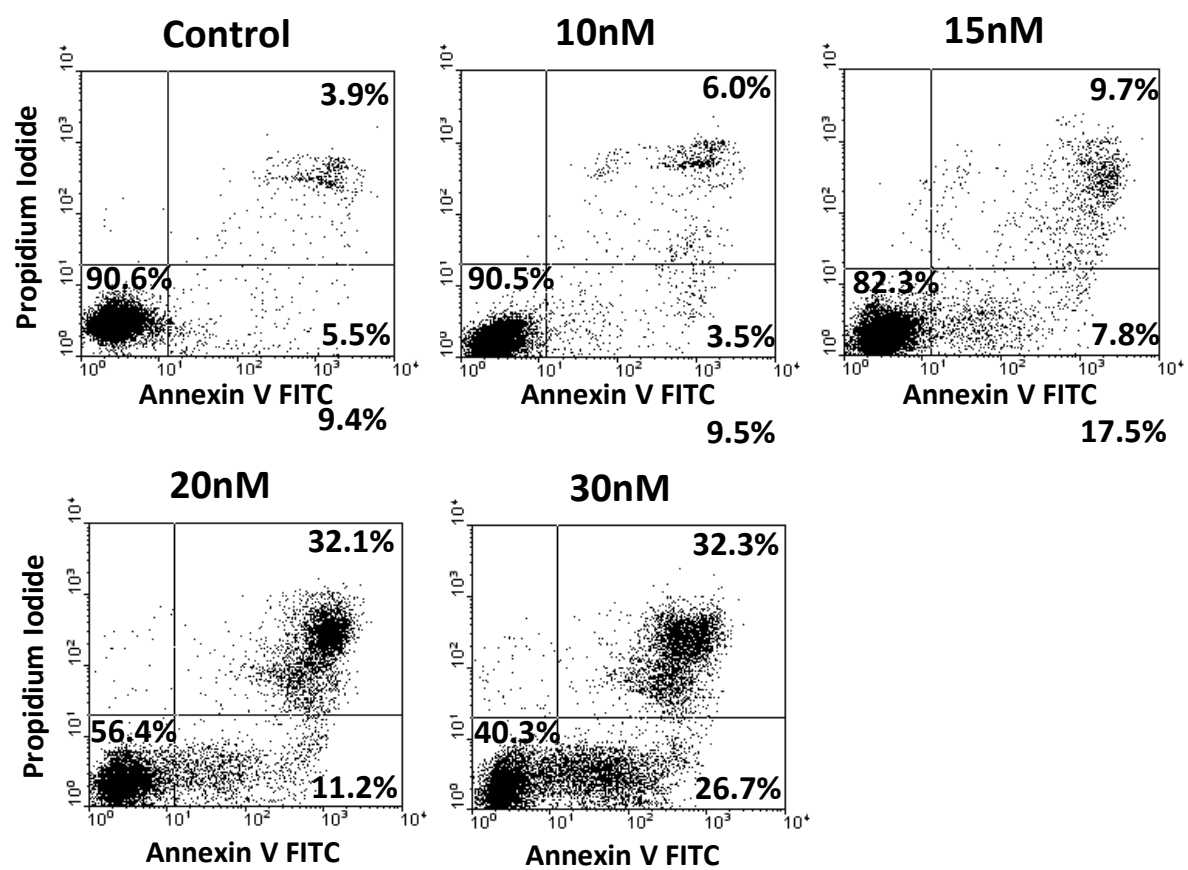

$43.3 \%$

$59.0 \%$ 
F.
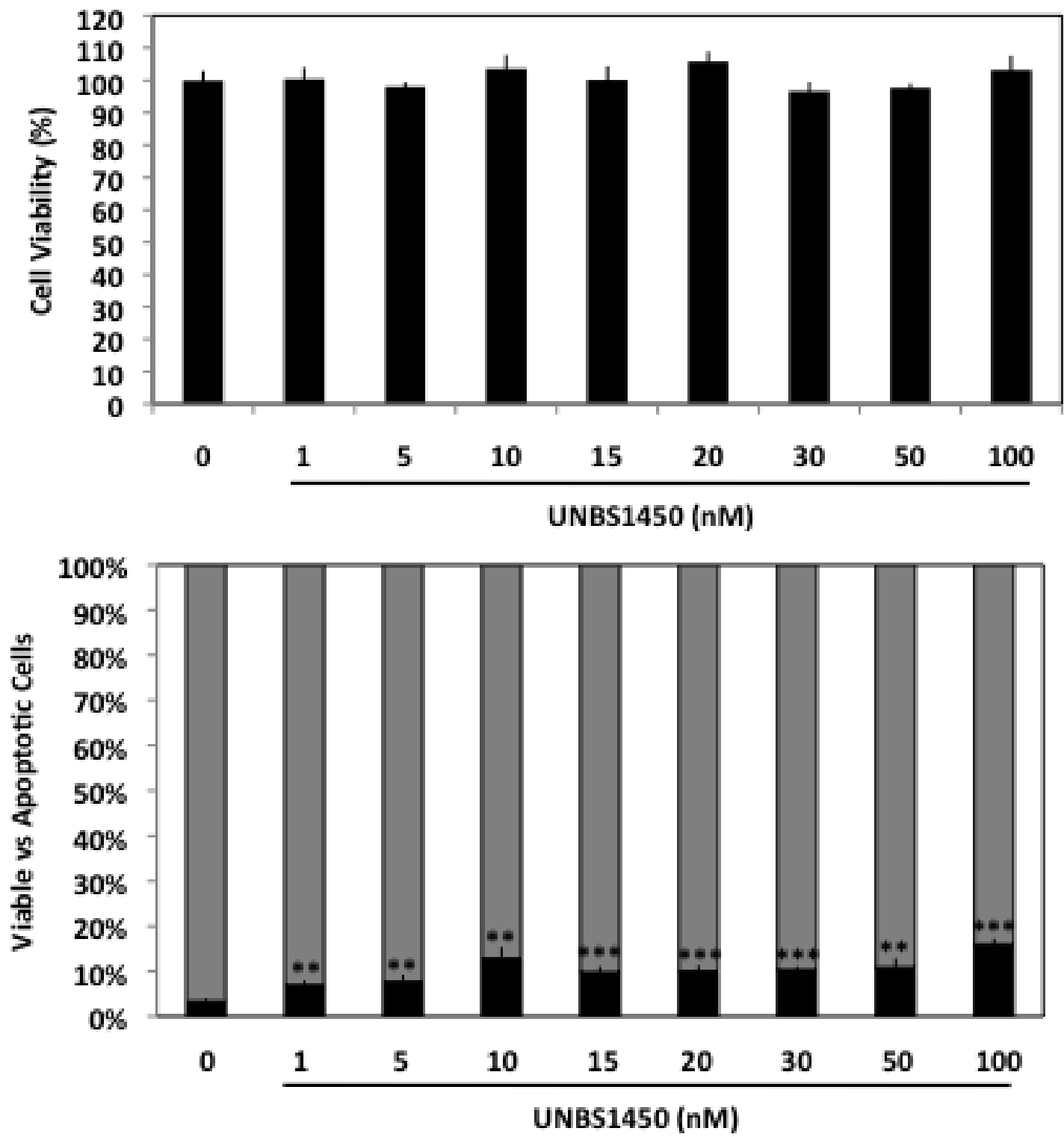


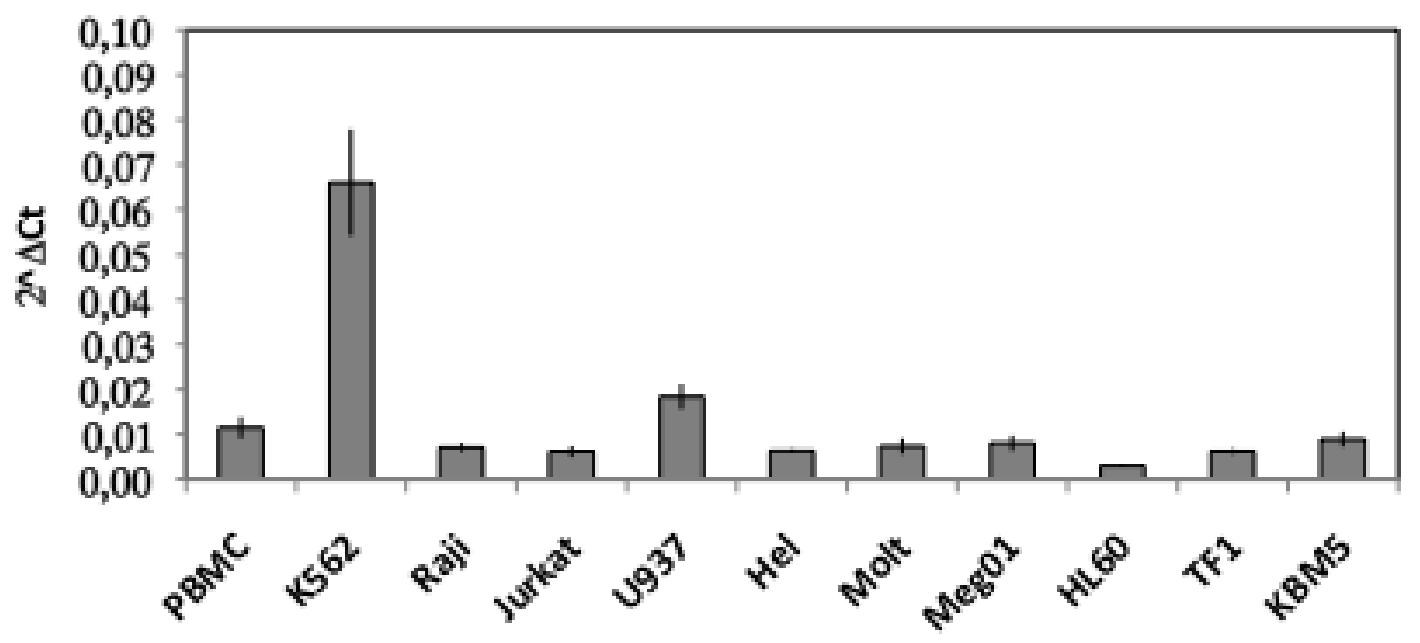

Figure 2 
A.
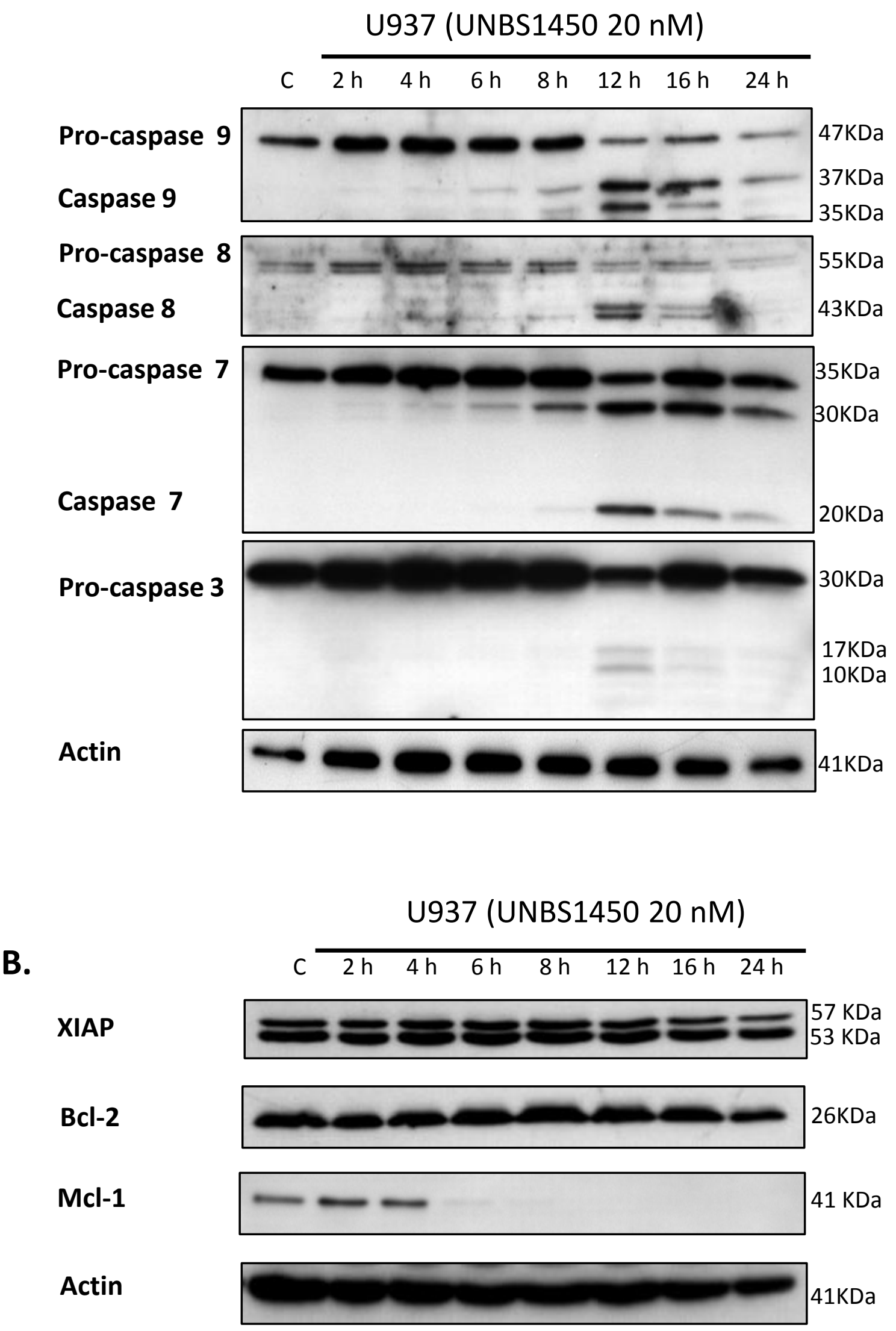
A.

Nucleus

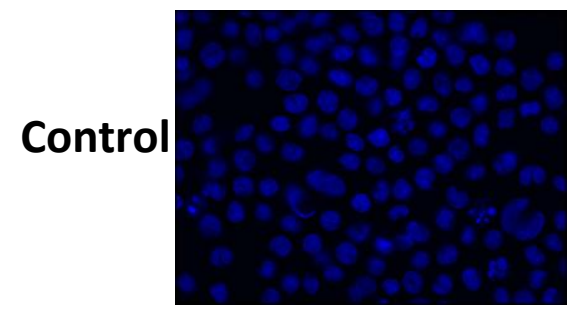

$10 \mathrm{nM}$

$15 \mathrm{nM}$

$20 \mathrm{nM}$
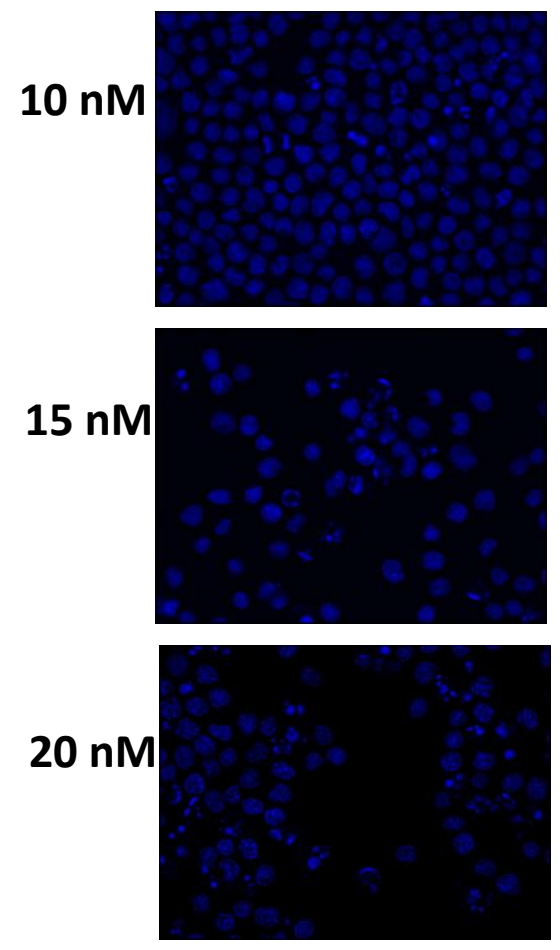

$30 \mathrm{nM}$

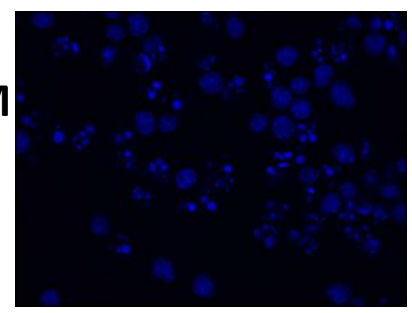

Bak Ab-1
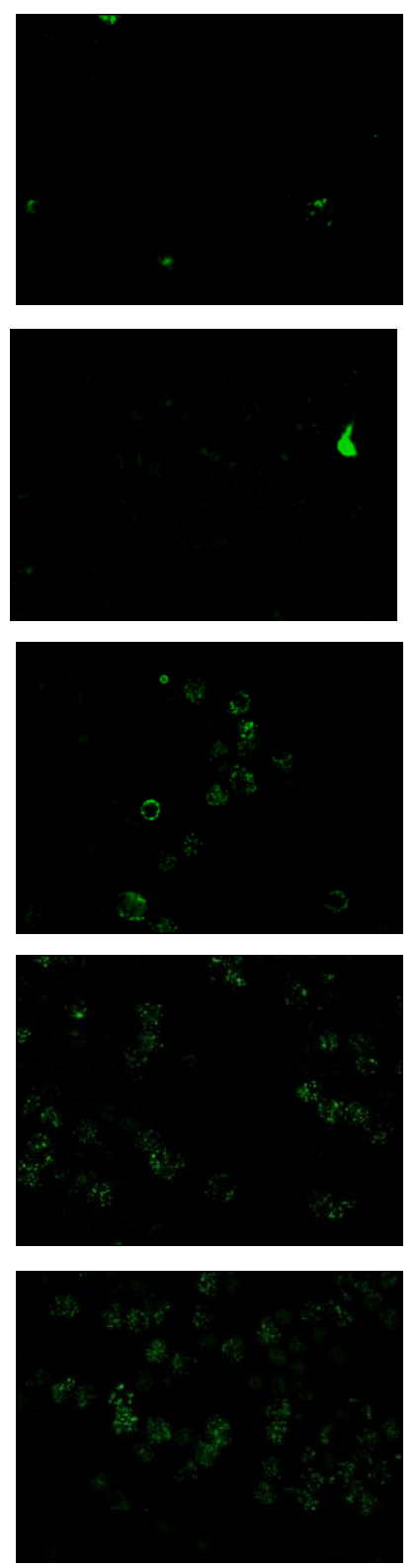

Merge
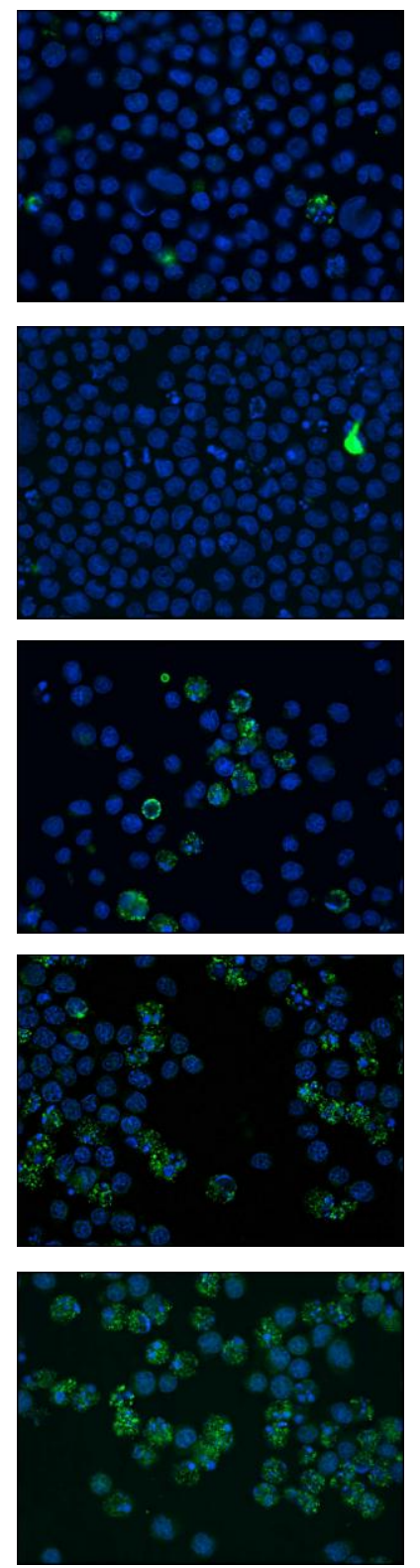

Figure 4 
B.

Nucleus

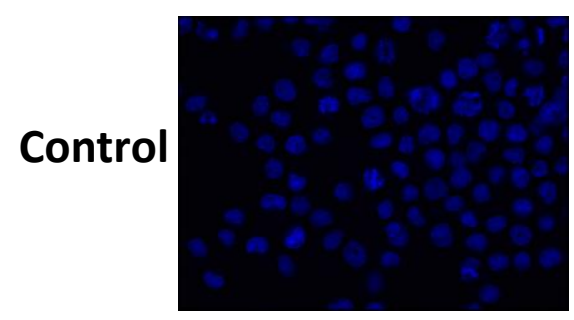

$10 \mathrm{nM}$

$15 \mathrm{nM}$

$20 \mathrm{nM}$
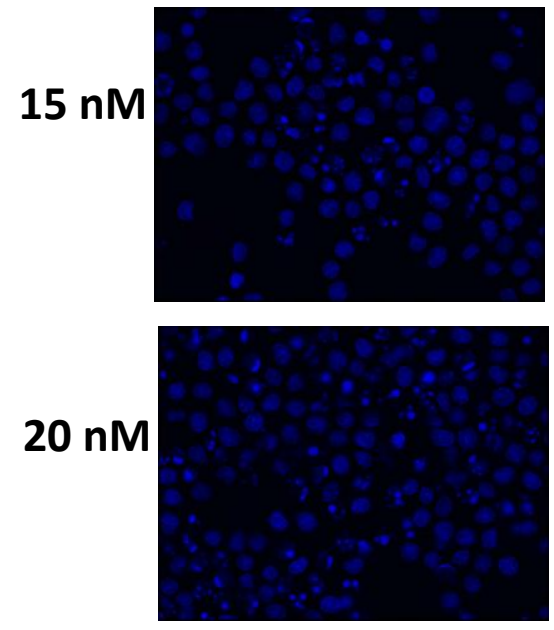

$30 \mathrm{nM}$

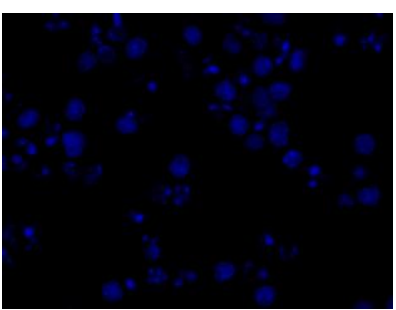

Bax 6A7
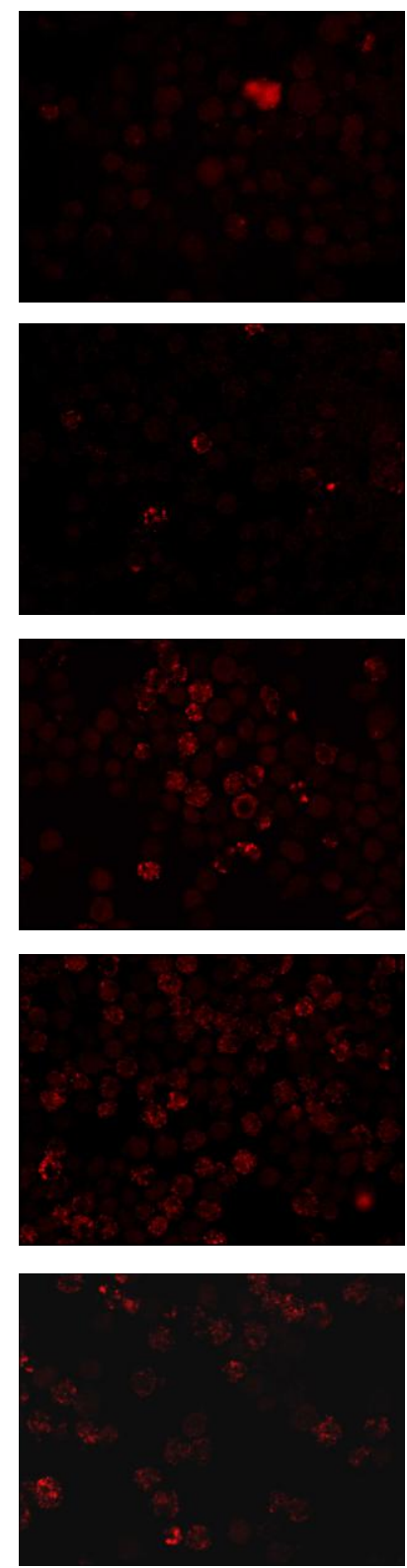

Merge
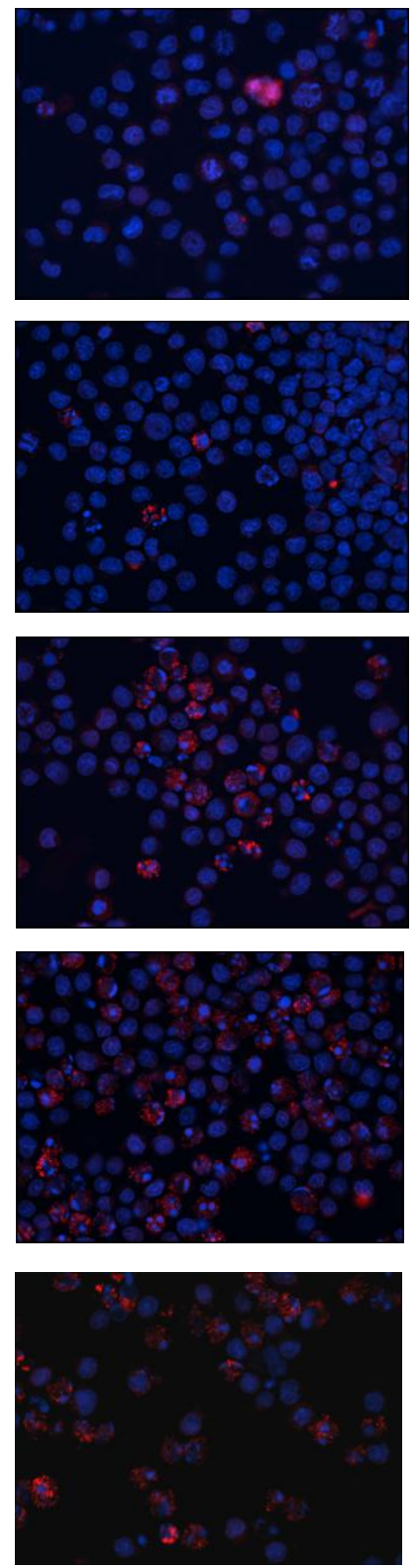

Figure 4 
A.

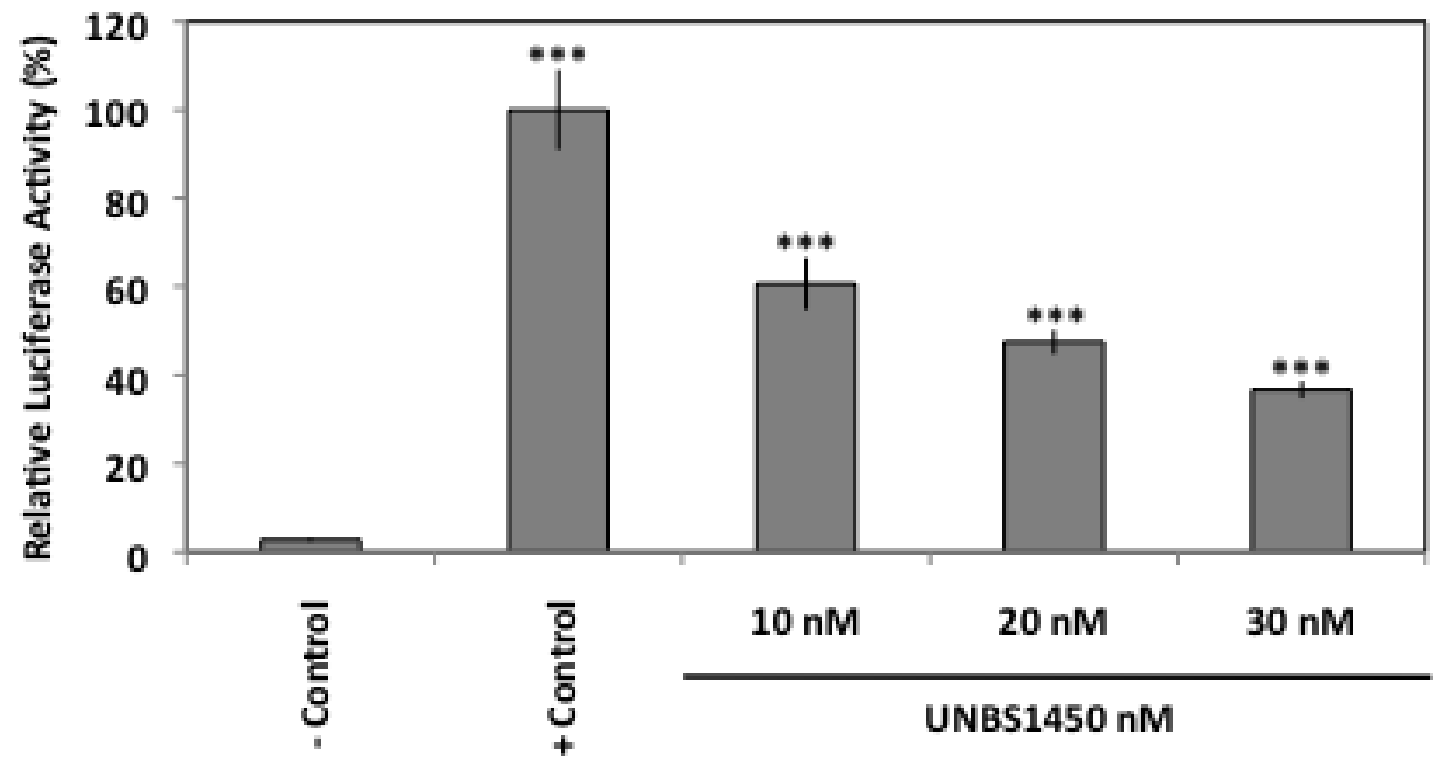

B.

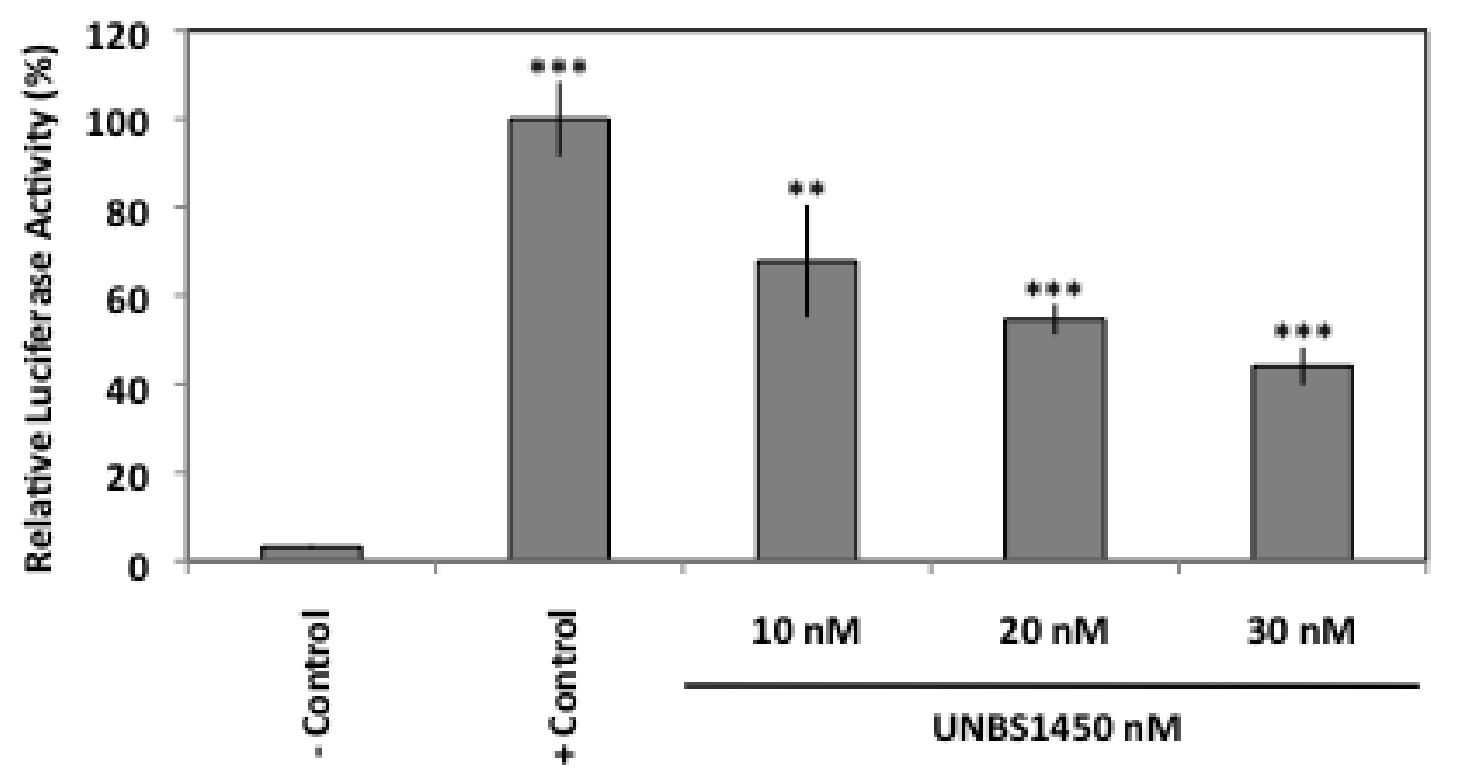

Figure. 5 
C.

Medium

TNF $\alpha$
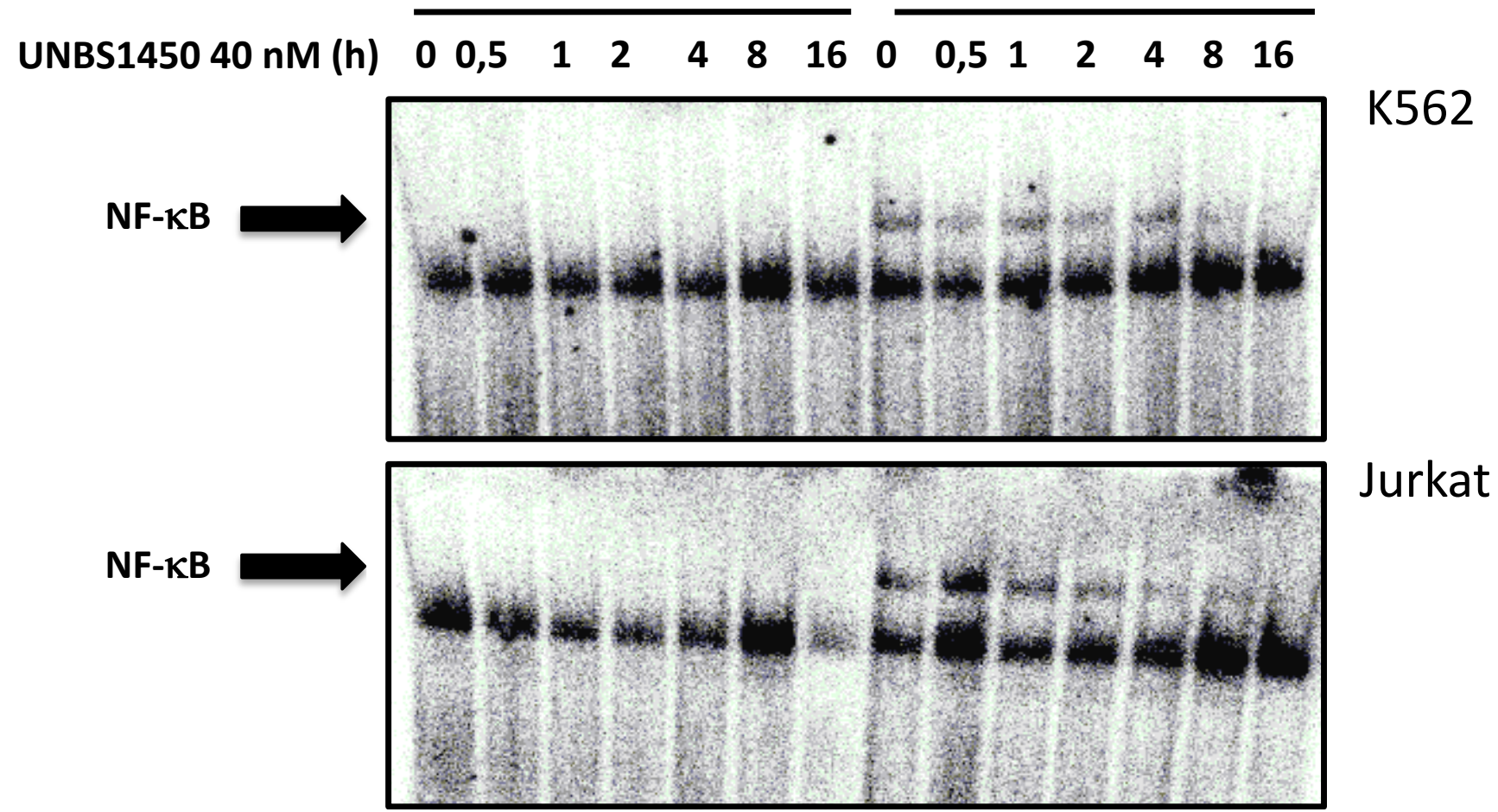

D.
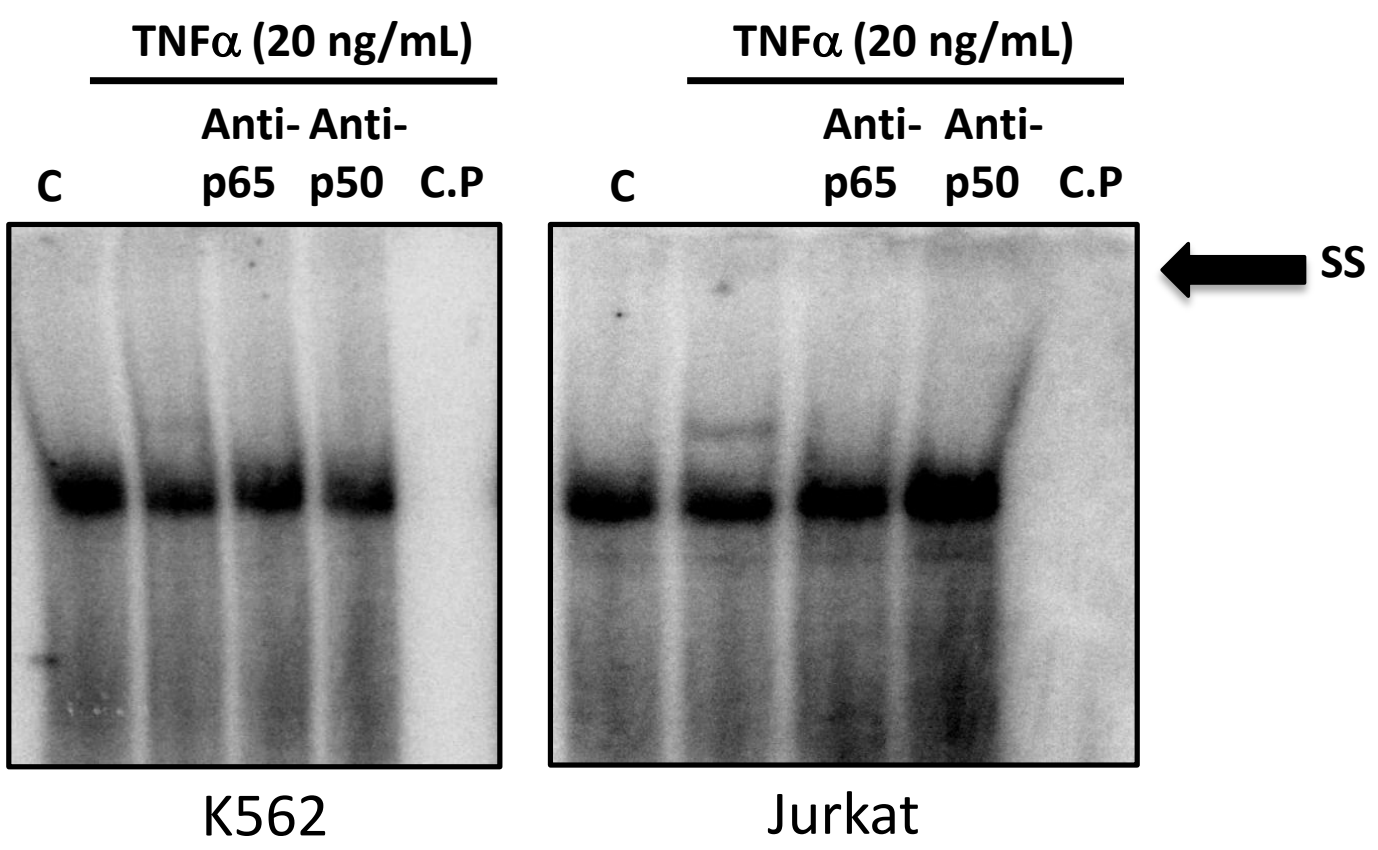

Figure 5 
E.

\section{Cytoplasm}
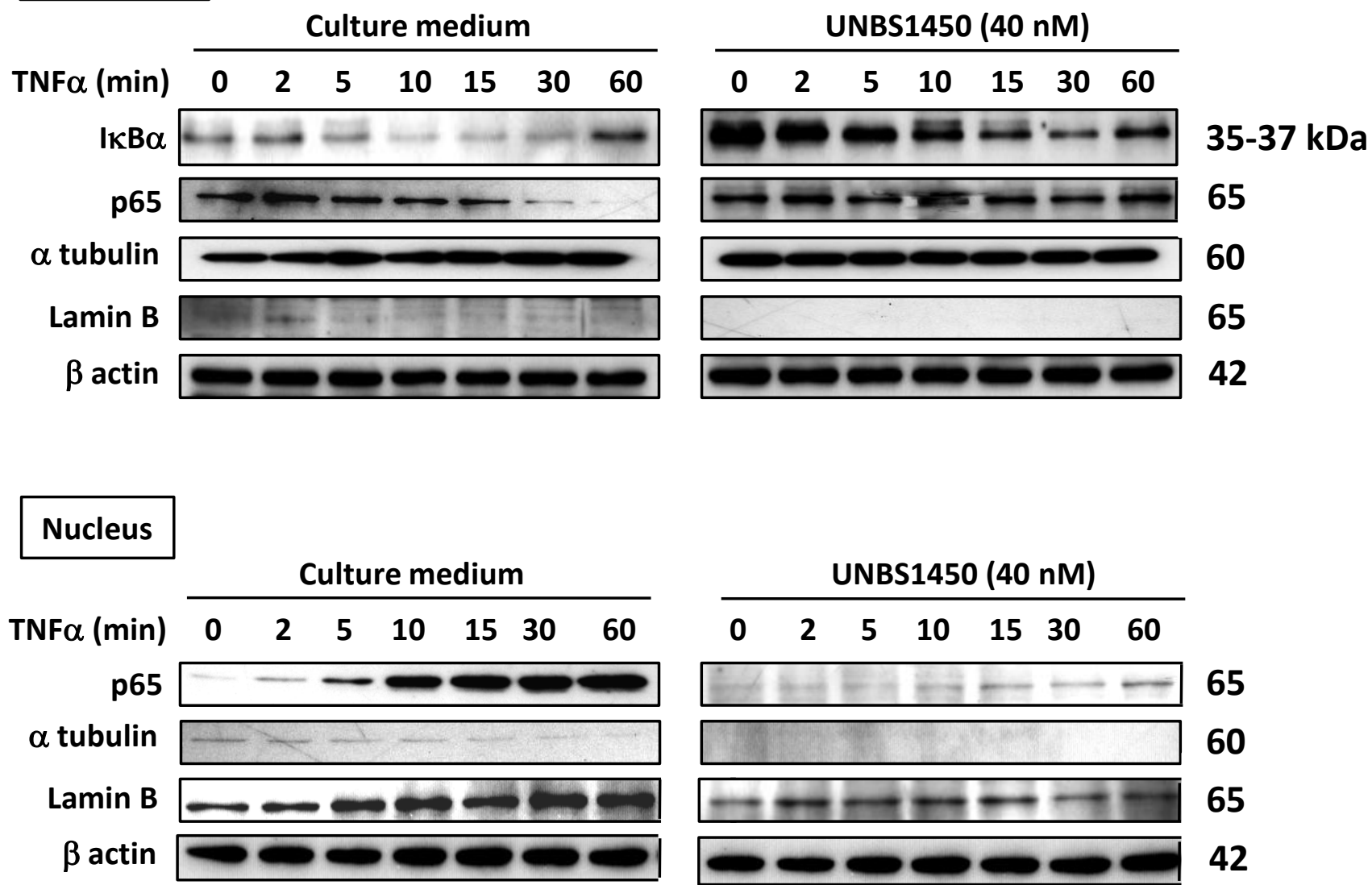
F.

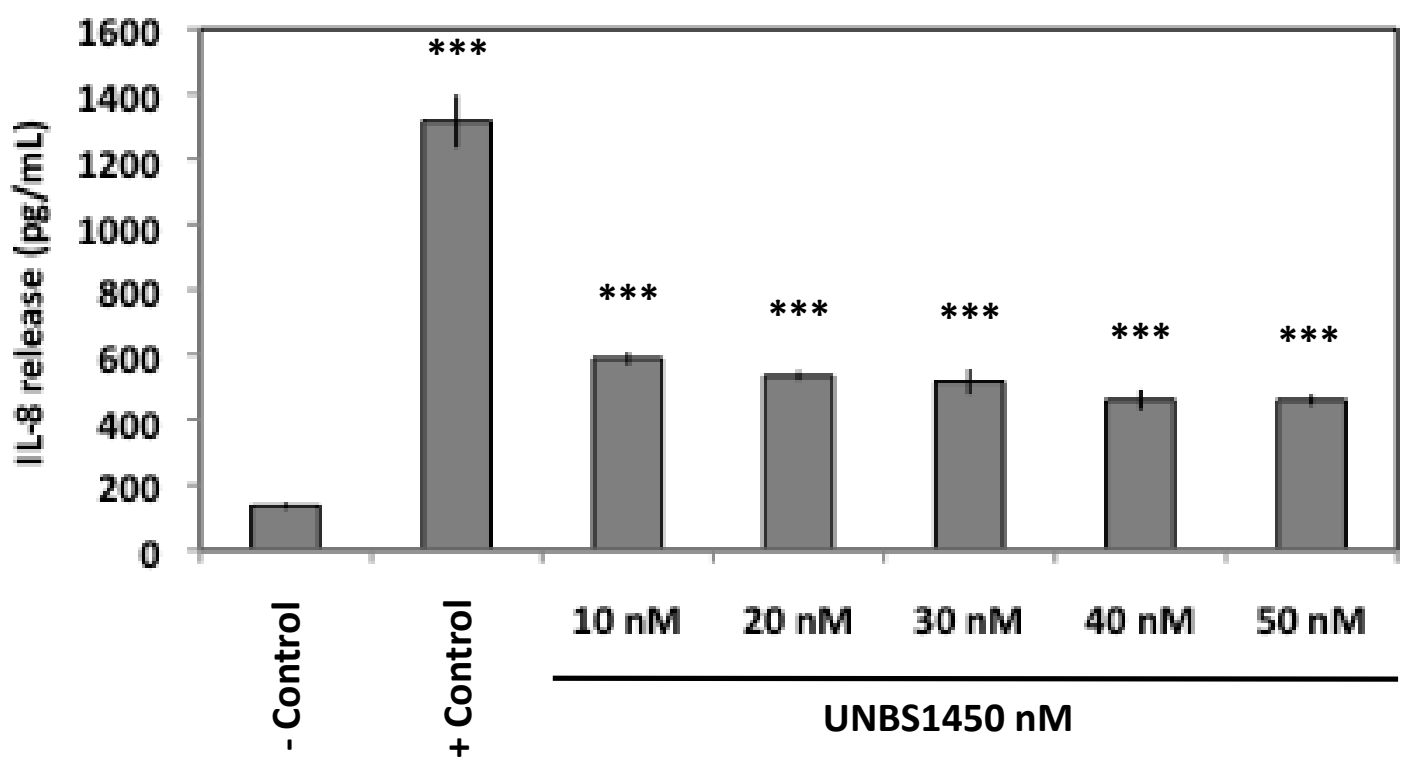

G.

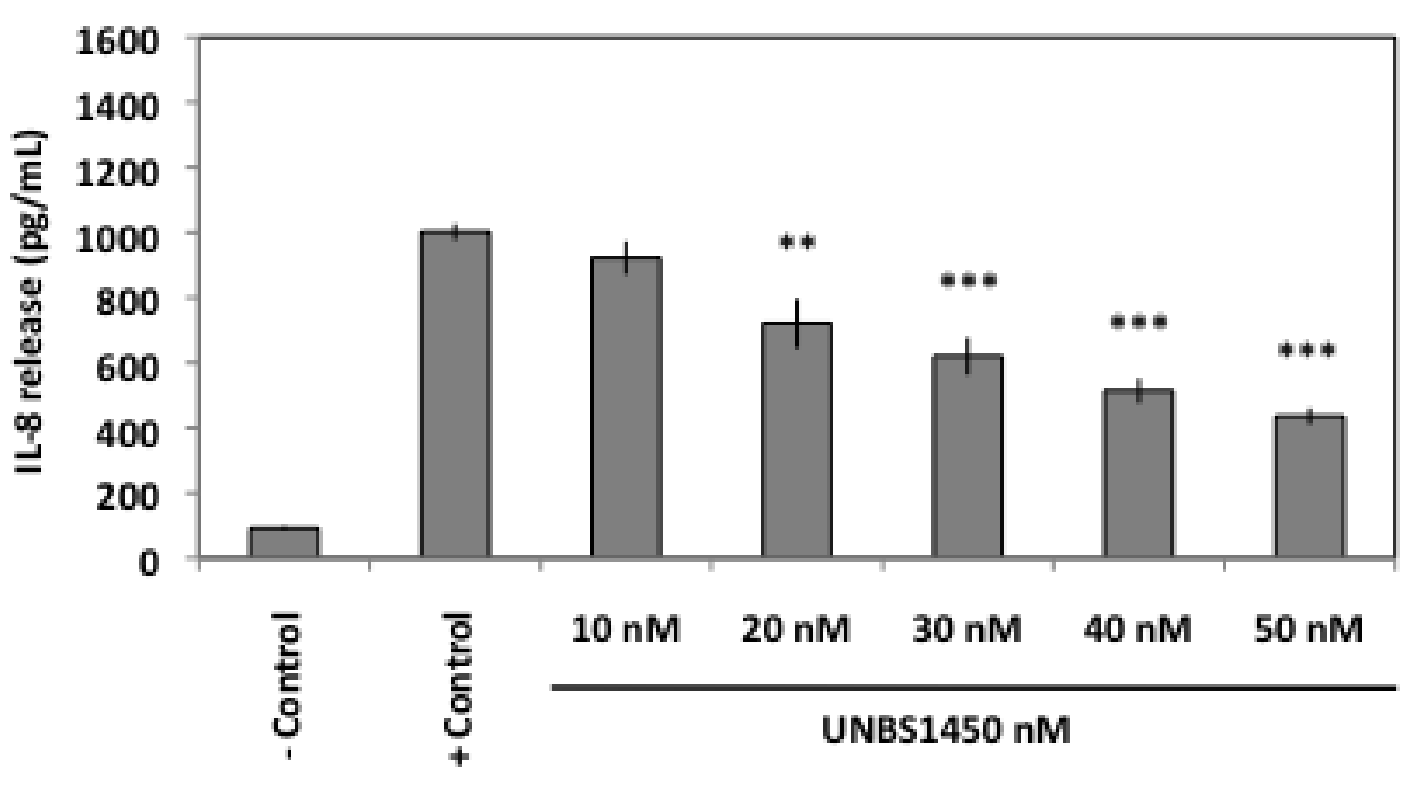

Figure 5 